On the margins of Ghana and Kawkaw:

Four seasons of excavation at Tongo Maaré Diabal (AD 500 - 1150), Mali.

\title{
Nikolas Gestrich
}

Frobenius Institute, Frankfurt

Norbert-Wollheim-Platz 1, 60629 Frankfurt, Germany

gestrich@em.uni-frankfurt.de

Kevin C. MacDonald

\section{UCL Institute of Archaeology}

31-34 Gordon Square, London, WC1H OPY, United Kingdom

kevin.macdonald@ucl.ac.uk 


\begin{abstract}
This article summarises the results of four seasons of excavation at Tongo Maaré Diabal (AD 450 -1100), near Douentza, Mali. Deep stratigraphic excavations were directed by MacDonald and Togola in 1993, 1995 and by MacDonald in 1996. Complementary, large exposure excavations of the abandonment layer were undertaken by Gestrich in 2010. The combined excavation results speak to topics of craft specialisation, trade, and social organisation. They provide evidence of a specialised blacksmithing community that is physically on the margins of early Middle Niger and Niger Bend statehood and urbanisation.
\end{abstract}

Le présent article porte sur les résultats de quatre saisons de fouilles sur le site de Tongo Maaré Diabal (AD 450 - 1100), non loin de la ville de Douentza au Mali. Des fouilles stratigraphiques en profondeur ont été réalisées par MacDonald et Togola en 1993 et 1995 ; et par MacDonald en 1996. Des fouilles complémentaires du dernier horizon d'occupation ont été réalisées sur une grande surface par Gestrich en 2010. Les résultats de ces campagnes portent sur des thèmes de la spécialisation artisanale, du commerce et de l'organisation sociale. Ils nous permettent de décrire une communauté des métallurgistes spécialisées, située en marges des anciens développements étatiques et urbains du Moyen Niger et de la Boucle du Niger. 


\section{Introduction}

The site of Tongo Maaré Diabal (the 'ju-jube tree-covered dune' in Fulfulde, henceforth TMD) is a settlement mound, 9 ha in extent, and approximately 3 to $4.5 \mathrm{~m}$ in elevation above the surrounding plain. It lies in a narrow strip of flatland between two sheer sandstone escarpments, the Bandiagara and the Dyounde, ${ }^{1}$ and is $1 \mathrm{~km}$ north of the modern town of Douentza (Figure 1). The 'gap' between the mountain ranges makes this area a major crossroads on land routes connecting Timbuktu and Gao to the Malian interior, as well as north-western Burkina Faso to the Niger Bend. The environs of Douentza, part of the greater Gourma region, also fall near the margins of the Sahel's two greatest first millennium AD polities: Ghana (or Wagadu, c.AD 400-1100) and Kawkaw (or Gao, c. AD 700-1100).

TMD was first documented by Kevin MacDonald and Tereba Togola during an archaeological survey of the Douentza area in 1993 (MacDonald 1994; MacDonald et al. 1994). This survey was intended to document the ceramic Late Stone Age (LSA) occupation of the area, but Togola was also interested in later settlements and conducted a test excavation at TMD. His $2 \times 2 \mathrm{~m}$ test unit, which did not reach sterile soil, revealed the remains of mudbrick architecture across two building horizons. A radiocarbon sample taken from the earlier horizon returned a date suggesting that the site was occupied in the fifth century AD, perhaps earlier (GX-19233, see Figure 2). Intrigued by this relatively early date, MacDonald and Togola returned in 1995, hoping that further excavations of the lower layers at TMD would allow them to document the transition between the ceramic LSA and the beginnings of metallurgy in the region. In this season, two $4 \mathrm{x} 4 \mathrm{~m}$ units separated by a baulk were excavated (Units A and B). Further radiocarbon samples, however, showed the date acquired in 1993 to have been an aberration, probably old wood, with the true period of TMD's occupation spanning the fifth through the eleventh centuries AD (Figure 2, Table 1), making it

\footnotetext{
${ }^{1}$ The Dyoundé plateau is also known in the literature as Gandamia (see Gallais 1975)
} 
contemporary with the floruit of urbanism and the beginnings of statehood in the Middle Niger and Niger Bend.

Despite the fact that the later dates meant that TMD could not provide data on the research questions MacDonald had originally hoped to address, it became clear that TMD nevertheless merited attention. This was for three reasons. Firstly, its earthen architectural remains were both precocious in date and exceptionally well preserved. Unlike many of Mali's excavated early urban sites in the Inland Niger Delta, mud-brick wall stumps at TMD remained standing to heights of a metre or more, and the date of the site's loaf-shaped mudbricks was amongst the earliest in the Sahel. Secondly, these well-defined structures held an abundance of wellpreserved in situ artefacts such as intact pots, large amounts of metalworking remains, a terracotta statuette and even carbonised textile fragments (MacDonald 1997/98). Finally, ironsmelting and working remains in the area were extensive, implying a potential early industrial role for the region. MacDonald returned to the site in 1996 to complete the excavation of Unit B and its baulk (Unit C), beginning another unit on the western dogleg of the site (Unit D), and excavating at the nearby iron smelting site of Boata. Despite good results, and the completion of a report to the British Academy (MacDonald n.d.), publication of the work on TMD has remained sporadic. Material from the site has appeared in various journal articles and book chapters (MacDonald 1992; MacDonald et al. 1994; MacDonald 1995; MacDonald \& MacDonald 2000; Bedaux et al. 2003; MacDonald \& Camara 2011; MacDonald 1997/98), but the research was never completed to a point of full publication.

In these preliminary articles, MacDonald had asserted the existence of two technically distinct, yet contemporary, ceramic assemblages at TMD - inferring the existence of multiple populations at or near the site (Bedaux et al. 2003). In 2008, Gestrich undertook a detailed restudy of the TMD ceramic assemblage as part of his UCL MA dissertation. His results 
confirmed the existence of two ceramic traditions developing side by side over the full run of TMD's occupation (Gestrich 2008). While Gestrich's MA study showed the potential for examining issues of long-term social differentiation at TMD, the inferences that could be drawn from the data were limited. This was due to the fact that, while the 1993-1996 excavations supplied a good developmental sequence, they were too localised to support meaningful interpretations concerning the wider spatial distribution of artefacts. This frustration was also encountered by Walicka Zeh and MacDonald (2004) in their analysis of architectural remains at the site, which raised interesting questions, but could not make effective generalisations due to the limited sample areas. For this reason, Gestrich took the decision to revisit TMD, and to undertake renewed excavations, this time not focussing on temporal development, but upon excavating a wider area to deliver more meaningful results regarding spatial organisation. To complement the original 'deep sounding' of 8 by $9 \mathrm{~m}$ (Units A, B and C), it was decided to excavate a larger contiguous area of the uppermost occupation horizon of TMD (Units E and F). To be able to make an assessment of intra-site variability, a further area of excavation (Unit G) was opened on a different part of the site, adding to the satellite Unit D from the 1996 excavations. This 2010 fieldwork, including renewed archaeological survey, was carried out as a PhD dissertation at the UCL Institute of Archaeology (Gestrich 2013).

Here we will present a summary of findings from our combined four seasons of excavation at TMD, including architecture, faunal and floral remains, pottery, and iron working. We will also review the results of the 1993 and 2010 surveys of the TMD area in order to discuss regional settlement patterns. Finally, in comparison with published data from the Middle Niger and adjoining regions, we will relate the finds from our excavations at TMD with wider historical processes. 


\section{The 1993-1996 Excavations at TMD}

\subsection{Excavations}

In 1993, 1995 and 1996 two 4x4m units were excavated, termed A and B, joined by a 1x4m baulk (C). This area was excavated to a maximum depth of $4 \mathrm{~m}$ before reaching sterile soil. The sequence of archaeological deposits in A and B was grouped into five horizons of superimposed earthen buildings. Based on marked continuities in architectural layout (see below) this occupation appears to have been continuous from the site's foundation at the beginning of the sixth century, to its abandonment, probably late in the eleventh century (Figure 2, Table 1).

A further 4 by $4 \mathrm{~m}$ unit (D) located on the western part of the site (Figure 3), was only excavated to a depth of $1.3 \mathrm{~m}$, well above sterile soil. On the basis of stratigraphy and material culture the excavated deposits appear to coincide with Horizons 4 and 5 from the large exposure A-B-C.

Seven radiocarbon dates provide a 650 year time span for the excavation's discrete sequence of building events (horizons). On this basis, and the relative thickness of deposits associated with them, we can divide each of these horizons into 100 or 150 year time blocks (see Figure 4). Two of the nine C14 determinations at the site (GX-19233 and 24104-LS) look to be on 'old wood'. The similarity between these two dates, and their comparable stratigraphic depth, could indicate that charcoal was at that point being widely mined from some ancient bush fire event, or that wood from long-lived trees was being burned at the site. 


\subsection{Architecture and Features of the Deep Exposure}

The deep exposure of A-B-C evidences a remarkable architectural sequence (Figure 4). The first occupational horizon at the site (AD 500-650) features a pair of linked, circular coursed earth structures (Figure 5). To the north of them there are shallow ash-filled features suggesting open air hearths. In Horizon 2 (AD 650-750) there is an abrupt shift to rectilinear structures made in both coursed earth and loaf-shaped mudbrick. Given that these new rectilinear structures follow the basic footprint of the earlier round houses, and that coursed earth forms then co-exist with mud brick structures at the site, suggests continuity in the face of new architectural ideas. In the north of the exposure two new structures are adjoined by what appears to be an animal pen, enclosed by traces of stake holes and filled with a layer of rich green-brown organic matter. Already a bi-partite division of space is forming, suggesting the existence of two separate concessions, north and south.

Horizon 3 (AD 750-900) marks the beginning of nearly three centuries of relative continuity in the spatial layout of the excavated area. To the north, a clear zone of fine layers of burnt earth, charcoal and working slag demarcates an area of iron working. Remarkably, in section the margins of this working area do not move for $120 \mathrm{~cm}$ of depth, suggesting some sort of structural stability anchoring it in place - perhaps a succession of brush hangars, much as still exist at modern blacksmith's workshops in the area. At first the northern structures established in Horizon 2 endure - though now built in mudbrick. However, after a brief period they are removed and the space is left open in Horizon 3 upper and Horizon 4 (AD 900-1000). Significantly, a mudbrick compound wall separating the north and south concessions is built around $\mathrm{AD} 750$, which stands along the same path until it is incorporated into a row of house walls in Horizon 5 (AD 1000 - 1150). Dense evidence for metallurgy remains in the northern concession throughout the rest of the sequence - a small forge being evident in the central structure during Horizon 5. Thus, this concession appears to have been occupied by a 
succession of iron-working specialists over a 400 year period.

In the southern concession the twin structures first established in Horizon 1 are cleared away in Horizon 3 and three mudbrick structures, both curvilinear and rectilinear, fill the space. In the upper portion of Horizon 3 the eastern house continues to be re-built, whereas the western ones are replaced by one in coursed earth. Amidst this lingering diversity of built technology, there are our first finds of terracotta drainpipes in layers of wall collapse (post c. AD 800). These are indicative of earthen flat-roofed structures requiring drainage. Also, in the upper portion of Horizon 3, a remarkable cluster of features emerge in the yard south of these structures. Within an ash-filled basin flanked by a flat boulder, a carbonised mat was found, in weave resembling contemporary Dogon potters mats. Its material has been identified as Hibiscus fibre and is $8 \mathrm{~mm}$ in thickness, and was accompanied by second finer textile fragment, also of Hibiscus (Fiona Handley pers.comm.) (Figure 6). While not in itself overly significant, in its immediate vicinity were fragments of raw kaolinite, polished red ochre and a substantial lump of raw clay. There are also a surprising number of inverted intact vessels in this area: nine in total (see below). Taken as a whole, it is highly suggestive that this area was a potter's workshop - an interesting companion to the enduring blacksmith's workshop to the north.

Horizon 4 (AD 900-1000) witnesses a repair of the southern wall of the western structure with coursed earth and the building of a second concession wall, apparently isolating the two structures from one another. It is also at this time that a small pit is dug beneath the doorway of the eastern structure, containing ash and the broken remains of a terracotta equestrian statuette. It has been suggested elsewhere that this may have been the trace of a magical act in the same vein as historic anti-horse shrines (MacDonald \& Camara 2011: 25-26). 
In Horizon 5 (AD 1000-1150) the northern concession shows the sudden construction of a row of three small mudbrick rooms lining the well-defined middle passageway. As noted above, metallurgical activity is still ongoing in the area with a concentration of working slag and burned earth within the room, possibly a forge. The southern structures likewise are modified to form a row of small rooms comparable to those in the north. Overall this is the most significant spatial modification of the area in two centuries and precedes the site's abandonment. These rooms will be better contextualised in discussion of the larger exposure of Horizon 5 presented below.

\section{The 2010 excavations}

The main exposure of the 2010 excavations was positioned directly adjacent to units A, B and $\mathrm{C}$, so as to maximise the area available for spatial analysis. An initial 9x5m trench, called unit E, was extended to the northwest by a further $7 \times 5 \mathrm{~m}$ area, unit $\mathrm{F}$, to give a total excavated area of $125 \mathrm{~m}^{2}$ (referred to as Exposure 1; Figures 3 and 7). In these two units, only the uppermost occupation horizon (c. AD 1000 -1150) was excavated, being between 50 and $80 \mathrm{~cm}$ below the surface. In total, twelve earthen structures were documented in Exposure 1. The structures were small, rectilinear, and mostly free standing. Each room had its own four walls, even if it was joined to another. This form of building gives the architecture a modular character with independent elements set either separately or spontaneously combined. The division into two domestic compounds, as suggested by Walicka Zeh and MacDonald (2004), and the course of the passageway running between them, became more clearly visible in the larger exposure.

Unit F contained a substantial building, made of two adjoining structures, which we also interpret as a working area for blacksmiths (Figure 16). These buildings, showing evidence of repeated exposure to high temperatures on walls and floors, contained four sub-circular 
earthen features, some of which appear to have held large pots, while one, made of thick clay rings and dimpled with fingertip impressions, was clearly a hearth. A further clay feature with two holes, set against a wall, was immediately recognised as a bellows emplacement by a Malian colleague, himself the son of a blacksmith. Indeed, we were able to observe very similar modern installations in blacksmiths workshops near Sofara in Mali. The floor deposits contained copious amounts of charcoal, iron objects, and slag. The finds in this area speak to the continued use of the northern concession as an iron workshop, as well as a domestic area. Following on from the blacksmith's workshop in Horizons 3 and 4, production seems to have shifted to this area, and to occupy more substantial structures than before. While we believe that the earlier workshop is likely to have been covered by a hangar or similar structure, as its limits are clearly demarcated and durable, the workshop in unit $\mathrm{F}$ consisted of one roofed building and one that had low mud-brick walls, possibly with a more ephemeral covering.

Exposure 2, a 7x4m unit on the eastern part of the site (Figures 3 and 8), showed features that were, in many respects, similar. The remains of five contiguous mud-brick buildings were excavated here. In the western half of the trench, buildings G3, G4 and G5 appear to form a complex with interconnecting doorways, while the triple thickness wall separating G1 and G5 might be a compound division, analogous to walls found in the sequence of A-B-C (Walicka Zeh \& MacDonald 2004).

The architectural division of space at TMD strongly suggests that the settlement was divided into compounds, presumably lineage compounds similar to historic regional settlement organisation (Walicka Zeh 2000). These compounds appear to have accommodated a wide range of activities including relatively intensive ironworking. Moreover, the compound divisions at TMD were remarkably stable: we see the passageway and compound boundaries 
in the same place through 500 years of occupation in Units A, B and C (Walicka Zeh \& MacDonald 2004). Within the compounds, the architectural syntax indicates that movement and communication was open, with private spaces at a minimum, while the main access restriction was at the entrance into the compound which appears to have passed through vestibules (Walicka Zeh 2000; Hillier \& Hanson 1984). In sum, the architectural layout appears to reflect that the main and most durable social boundaries lay between domestic compounds. This in turn strongly suggests the existence of co-habiting lineage groups.

As indicated above, there are two main building techniques at TMD - loaf-shaped mud bricks and coursed earth. The former technique is suited to builders who are able to dedicate a large portion of their time to building, as it requires more careful pre-planning and preparation (i.e. fashioning and drying a requisite number of bricks), but once building has begun, structures can be quickly erected without the need for interruptions. Coursed earth techniques, on the other hand, require comparatively little preparation, and can be carried out by unskilled individuals in small portions at a time, as one course of earth is laid and has to be left to dry before the next can be added. While there does seem to be some temporal development in building techniques at the site, with the earliest occupation horizon being built in coursed earth only (Walicka Zeh \& MacDonald 2004) demonstrate that techniques occur side by side throughout the rest of the sequence. So far, we can only guess at the reasons for this. It is unlikely that building techniques are linked to the function of buildings, as we have an example of a building that is made using a mixture of techniques. Instead, they could be determined by the availability of specialists, factors of time and labour, or as an expression of social values or status.

\section{Survey: The Local Context of Tongo Maaré Diabal}

The survey of the Douentza area by MacDonald and Togola in 1993, while focused on Late 
Stone Age remains, also documented all sites encountered from more recent periods. Carried out from a vehicle, this survey only documented sites visible from along the area's navigable tracks. A renewed survey in 2010 provided total coverage of all 'Iron Age' sites within $10 \mathrm{~km}$ distance from TMD, thus placing it in the context of its immediate pedestrian radius.

However, our knowledge of the area's archaeology remains limited to the open plain between the two escarpment ranges, since the escarpments and plateaux are extremely difficult to access. Only one, seemingly post $12^{\text {th }}$ century, site is known from the northern end of the Bandiagara massif at Fombori. Apart from this, our 1993 and 2010 surveys documented fifteen sites in a 5km radius around TMD (Figure 9), of which ten were habitation mounds (tells) and five were iron smelting sites.

The habitation mounds all bear clear similarities to TMD, both in size (none are larger than 15 ha, and all appear to have around $3-5 \mathrm{~m}$ of stratigraphy) and in surface material culture. This is characterised by the coexistence of two main pottery traditions (see below). As both Ceramic LSA (up to $500 \mathrm{BC}$ ) and recent historic pottery from the area is reasonably well documented, it is possible to claim a rough contemporaneity for all of the surveyed mounds. Also featuring pottery of the TMD tradition are three iron smelting sites, of which one (Boata North, Figure 9) returned an AMS date contemporary with TMD's earlier levels (251-620 cal. AD). It is also noteworthy that all of the habitation mounds showed extensive evidence of iron metallurgy on their surfaces.

In general, the area around TMD displays a settlement pattern that is distinctly different from the urbanised Inland Niger Delta, with evenly spaced medium-sized ( 5 to $15 \mathrm{ha}$ ) sites rather than urban clusters with sites of variable sizes. Jenné-jeno, for instance, has a total of 69 sites within a 4 km radius, including large central sites (McIntosh 1991), and R. McIntosh estimates the population of the entire cluster at its apogee to have been c. 50,000 (McIntosh 
1998: 200). In contrast, the area around TMD features only discrete medium-sized settlement sites that are spread across the landscape without any clustering - or even twinning. There thus does not appear to have been a central urban focus to settlement here, as was present in the IND with sites such as Dia and Jenné-jeno. Instead, the settlements give the metrical and surface feature impression of having been autonomous units not growing out of a 'selforganising landscape' (senso McIntosh 2005). Settlement here thus appears to be uncentralised, a peripheral rural counterpart to the urban core areas of Middle Niger and Niger Bend civilisation.

Following Walicka Zeh (2000), the single-mound, nucleated nature of the settlements can be caused by two factors, either environmental pressures such as flooding (and the need to build on patches of higher ground), or social pressures (mainly the need for defence against outside aggression). Both of these are distinct possibilities for TMD and its neighbouring sites. The 1995 and 1996 excavations indicate that sterile soil begins approximately $75-100 \mathrm{~cm}$ above the surrounding plain. This would indicate that the site was settled on a low rise at the margins of the ancient floodplain. However, we cannot be certain of the amount of flooding that occurred in the area during the first millennium AD. Beyond the immediate vicinity of the Dyoundé/Gandamia escarpment there is the 'lacustrine Gourma' (Lac Korarou and environs) which today lie approximately $40 \mathrm{~km}$ to the north-west of Douentza. This network has received floodwaters from the Niger as recently as the 1970s, but since then has existed only as an isolated ponding area (Blanck et al. 1996). Locals have recounted years in the 1950s and 1960s when the flood (crue) attained Débéré, only $10 \mathrm{~km}$ from the western tip of the massif. However, Blanck et al. (1996) state that strong and persistent overflows from Lac Korarou to the west probably did not continue after the beginning of current climate conditions (Blanck et al. 1996, 117). Despite this, moderate quantities of fish remains from the site indicate some proximity to the Niger's floodwaters throughout its occupation (see below). 
There are also indications that life in this area was not always peaceful and that settlements might have needed to defend themselves, possibly from raiding parties, as has been inferred from the terracotta horse and rider statuette described above (MacDonald \& Camara 2012; Bedaux et al. 2003). One of the sites documented during the 2010 survey, Tongo Maaré Sanga (Figure 9), does appear to have been fortified with a wall or rampart consisting of mud and small stones running around the site, similar to fortifications documented in $18^{\text {th }}-19^{\text {th }}$ century Ségou by MacDonald (2012). The fact that no such structure has been discovered at TMD does not mean that the village was not fortified, as the house and compound walls could have functioned together as a defensive boundary. Neither must we imagine that human aggression is the only reason to nucleate a settlement - in many documented cases settlement boundaries function to keep inhabitants safe from malevolent spirits that inhabit the countryside around the settlements (ibid.; Walicka Zeh 2000).

There is also some indication that mobile pastoral populations also inhabited the area around TMD at certain times of the year, as evidenced at Orowal Débéré (Figure9). There, the small but high tell is surrounded by a large zone of scattered artefacts in small concentrations, which are partially revealed by low moving dunes. These comprised pottery and grinding basins, but no apparent architecture, calling to mind the seasonal occupation by pastoralists of the outskirts of permanent agricultural settlements common in the area today.

\section{Faunal Remains}

TMD's faunal record is varied, containing domesticated and wild mammals, avian remains, and fish. Judging by the NISP of each class (Table 2), the most important animal resource for TMD's inhabitants were bovids (NISP 748), followed by fish (229), dogs (224), and birds 


\subsection{Bovids:}

Bovids are the most numerous category of faunal remains at TMD, making up at least $50 \%$ of the assemblage in any horizon, and up to more than three quarters of remains in Horizon 3. Both domesticated and wild bovids are present at the site. In the majority of cases, bovid specimens are not diagnostic to species level and are thus classed according to size:

— large (animals at the larger end of domesticated cattle, along with wild bovids the size of Eland and Buffalo, though the latter are not otherwise documented at TMD)

— large medium (animals the size of domesticated cattle, along with larger antilopes, e.g. Kobus sp..)

— small medium (animals the size of domesticated sheep and goats, but comprising a range of possible wild bovid species. Despite probably being dominated by domesticated animals, we can expect some wild species to be present within this category at TMD)

— small (animals too small to be domesticated ovicaprids, since dwarf goats are not in evidence at TMD. This category thus probably consists of small antelopes such as Sylvicapra grimmia and Ourebia ourebi).

The vast majority of bovid remains in every horizon are of the small medium size class, containing domestic ovicaprids and medium antilopes. Together, they make up at least two thirds of the bovid remains in every horizon. Their relative dominance over the combined large and large medium size classes and identified Bos sp. remains suggests local small-scale stock-keeping to have provided the bulk of meat at TMD. Cattle are apparently rare at the site until Horizon 3 (post AD 750), potentially indicating greater cattle-keeping or pastoral presence in the area after that time. So, the inhabitants of TMD may themselves have kept no 
or only few cattle, instead acquiring them from mobile pastoral groups. The existence of such groups at the time is hinted at by the evidence of temporary settlement around the site of Orowal Débéré (see above).

The remains of wild bovids in the assemblage indicate that hunting took place in the rural bush areas around TMD. Animals such as red-fronted gazelle (Gazella rufifrons), common duiker (Sylvicapra grimmia), reedbuck (Redunca redunca), or hartebeest (Alcelaphus buselaphus) are all present, but do not make a large contribution to the diet at TMD. However, the social importance of hunting might well have contributed this practice. In recent times, hunting in Mali was carried out by hunters associations, more for ideological, spiritual and social reasons than for dietary needs (Duran 2000; Cashion 1982; Cissé 1994). As a proxy for habitats and landscapes, the wild bovid remains appear to reflect a wide variety of habitats, ranging from open and arid steppe to wetter grassland and woodland mosaics.

\subsection{Dogs:}

Dogs make an important contribution to the faunal assemblage at TMD. The three species of Canis that occur in West Africa are difficult to separate osteologically, especially as the TMD sample is mostly too fragmented for morphological criteria (Osborn \& Helmy 1980). However, where osteometric distinctions on mandibular elements (e.g. MacDonald \& MacDonald 2000) could be used, the specimens were all domestic dogs (Canis lupus familiaris). Dogs were thus kept at TMD, apparently for a number of reasons. Besides being inferred participants in hunting and guarding, dogs also appear to have been important for food and in ritual contexts.

The use of dogs as a food source is suggested by the pre-depositional fragmentation of the remains as well as, more concretely, by the frequent occurrence of butchery marks and 
charring. Cynophagy is well-known in West and North Africa (MacDonald \& MacDonald 2000; Linseele 2003; Linseele 2007), and has also been evidenced in archaeological remains from the Senegal valley at the early first-millennium AD sites of Cubalel, Siouré (MacDonald \& MacDonald 2000) and Tulel-Fobo (van Neer \& Boucoum 1991).

The ritual role of dogs appears in the striking find of a dog skull and several long bones arranged on a pot base, buried in the passageway of Horizon 5. Rather than being the full inhumation of a favourite animal, the partial nature of the remains suggests a connection to ritual or magic. Recent excavations at the site of Sadia in the Seno plain (Huysecom et al. 2015; Huysecom et al. 2011) have revealed similar dog inhumations in pots (Chrystel Jeanbourquin pers. comm.).

\subsection{Rodents:}

Rodent remains are in evidence from Horizon 3 onwards. Especially in the assemblage from 2010 there is evidence of a sizeable infestation, with rodent remains at $11 \%$ of the total NISP (not represented in Table 2, since most remains could not be identified beyond the order Rodentia). While there are the occasional identifiable remains of large edible rodents (Crycetomys gambianus and Thryonomys swinderianus), most are smaller commensals. The common occurrence of rodent gnaw marks on the faunal assemblage suggests that TMDs inhabitants shared their space with rats and mice, which both poses a threat to food stores and can be a dangerous disease vector. This might also be the reason why we find the appearance of small amounts of (probably domestic) cat remains in the uppermost horizon post AD 1000 (NISP 8).

\subsection{Birds:}

The assemblage contains the remains of several species of fowl, both domestic and wild 
(Gallus gallus, Francolinus sp. and Numida sp.). Domestic chickens (Gallus gallus) are in evidence from Horizon1 (AD 500) onwards, and are thus amongst the earliest documented occurrences in West Africa (MacDonald 1992, 1995; Dueppen 2011). Non-phasianid bird remains are mainly from: the genus Streptopelia (the dove family), Anhinga (darters) and one tibiotarsus of a small member of Anantinae (dabbling ducks).

There are also finds of eggshells which could be separated by their thickness into domesticated chickens on the one hand, and Numida and/or Francolinus on the other (Gestrich 2013: 177; cf. Dueppen 2011 and Linseele 2007). In the 1993-96 sample (combining all Horizons), 73\% are from Numida or Francolinus, with all 6 samples of Gallus eggshell coming from a open yard context in Horizon 4. In the 2010 sample, coming from Horizon 5 only, Gallus becomes numerically dominant (Figure 10). Although inconclusive, this eggshell data might imply the keeping of guineafowl (Numida), indicating potential domestication - a subject upon which osteology appears to provide little information (see MacDonald 1992; MacDonald and MacDonald 2000). That said, bones attributable to Numida are relatively rare at TMD, and these eggs may equally have come from raiding the nests of local wild birds.

Birds are also found in ritual contexts, as is evidenced by three finds of buried, intact and articulated chickens (Gallus gallus). Two of these (both adult birds) were recovered from within one of the ash-filled depressions in unit A, Horizon 1. They date from the very foundation of the site, potentially as sacrifices prior to the building of a new compound. The third chicken inhumation comes from the site's abandonment, buried (like the dog skull) in the Horizon 5 passage between the north and south compounds (Unit C, context 3). The use of the chicken in ritual life has a long history in West Africa of which these are early examples (MacDonald 1995). 


\subsection{Fish}

Fish remains are relatively uncommon at TMD when compared to Inland Delta sites like Dia or Jenné-jeno (totalling just a few more than 200 total NISP across all horizons). This is probably for ecological reasons, with only occasional and seasonal proximity of the Niger floodplain. While Clarias can still be found in seasonal ponding areas around Douentza today, most of the remaining taxa would require waters linked to the Niger floods - if only shallow ones. Only a few larger specimens $(50 \mathrm{~cm}+)$ of Lates niloticus recovered from the site would have come from principal channels. Such deep channel fish would likely have been brought to TMD by trade, possibly in smoked or dried form.

Interestingly, in the 1993-1996 excavations, fish remains were virtually absent from the upper three horizons of the southern concession. This raises the question whether the consumption of fish was subject to restrictions for some parts of the population. Unfortunately, the 2010 excavations were not able to shed much light on this question, as only one further building in the southern concession was excavated, though it too did not yield fish remains

\subsection{Conclusions (Faunal Remains)}

Overall, the faunal remains at TMD show us a society where domestic animal consumption dominated, but where wild animal foods also had some importance. In most cases we might assume that the inhabitants of the site itself were responsible for raising the animals, hunting and fishing, but there are some instances, including some fish and probably cattle, where food resources were traded into TMD. We are also able to note that animals played a role in ritual life at the site, particularly dogs and chickens which were found in contexts that do not suggest straightforward consumption. 


\section{Botanical remains}

The botanical assemblage at TMD is currently under re-study by Louis Champion as part of a $\mathrm{PhD}$ dissertation at the UCL Institute of Archaeology. Here, we can report on the results of preliminary studies of the flotation samples by Cecilia Capezza (n.d.) and of wood charcoal by Dirk Uebel (n.d). Capezza's analysis treated 11 of the 101 flotation samples collected during the 1993 and 1995 excavation seasons, and were limited to unit A. The samples were processed by mechanical flotation and passed through $1 \mathrm{~mm}$ and $25 \mu \mathrm{m}$ meshes. Uebel analysed 7,027 charcoal specimens from 87 contexts, all from the 1993-1996 excavation seasons .

Together, these botanical analyses suggest that the immediate vicinity of TMD was a savanna mosaic under heavy and constant cultivation. This system combined the growing of millet, evidenced by the seeds and involucres of Pennisetum $s p$. which dominated the assemblage, with the exploitation of stands of trees, including Acacia albida (apple-ring acacia, which is strongly paired with field clearance and millet agriculture historically in the Sahel; Wickens 1969). Other important tree taxa include Tamarindus indica, Ziziphus sp., Sclerocarya birrea and Lannea sp.. From Capezza's analysis, the farming of millet appears to have been practised to the exclusion of other domesticated grains. Material evidence for local grain processing includes large stone grinding basins in some rooms, as well as frequent finds of hand grinders throughout TMD's sequence. Additionally, at least some of the trees had dietary importance to TMD's population, as is evidenced by the common occurrence of fruit stones of Ziziphus and Sclerocarya birrea on the site. Others, such as the seed pods of Acacia albida, are more commonly used for animal fodder, as were grasses such as Digitalia horizontalis and Dactyloctenium aegyptum, though the latter is also sometimes also consumed by humans. 
Beyond this intensively farmed zone, Uebel (n.d.) suggests the existence of a less intensively cultivated zone in which species such as Combretum glutinosum, Guiera senegalensis, Philiostigma sp. and Terminalia sp. thrived. His analysis shows that, unlike today, the region retained areas of gallery forest, from which the population of TMD took building materials (Celtis integrifolia) and firewood (Mitragyna inermis, Balanites aegyptiaca, Prosopis africana). Khaya senegalensis, also part of the stands of gallery forest, is found as a main constituent in the charcoal of the ironworking contexts at TMD as well as in the excavated furnaces at Boata.

Neither Capezza nor Uebel were able to demonstrate any temporal trends in their botanical analyses, suggesting that the impact of settlement at TMD on its landscape was limited. This is somewhat surprising and suggests that TMD was founded within an already established agroforestry system (or at least one that was quickly established after initial settlement). It also appears to tell us that the metallurgical activity at TMD did not have too great an impact on the remaining gallery forest. Louis Champion's re-study will attempt to shed more light on the development of TMD's surrounding landscape and its use.

\section{Pottery}

\subsection{Description:}

As was mentioned above, the most striking characteristic of the TMD pottery assemblage is the co-existence, from foundation to abandonment, of two ceramic traditions which differ markedly in forming technique and general appearance. The initially more prevalent of these, Tradition A, is made by pounding over a concave mould lined with a straight woven mat of twisted fibres. This technique, still very much in use in the TMD area today and considered typical of Dogon pottery (Gallay et al. 1998: 64-68), leaves distinctive mat impressions which 
cover the vessel's surface unless smoothed away. This practice, coded as MAT, can be considered as both a decorative and technical choice. To the pot body formed in this way, a rim is added by coil-building. These are frequently simple rims, or they may be everted or collared (Figure 11). The coil-built area is sometimes left otherwise undecorated, but most often cord roulettes are found on this part of the pot (74\% twisted cord roulette [CR6], infrequently also cord-wrapped roulettes [CSR] or dragged organics/straw [GRASS]). The pots of this tradition are never painted; on rare occasions the lip of the rim is slipped or burnished.

The second and ultimately numerically dominant pottery group is Tradition B. These pots all appear to have been made by pounding out a rounded base over a convex mould, such as an upturned pot to which the upper portions and the rims were added by coil-building (Keita 2011: 155-156, 2015). The vessels of this tradition also have a relatively standardised decorative grammar: in addition to painting (sometimes polychrome) they feature horizontal bands of rouletted motifs. Amongst these, a complex braided cord roulette (CCR) is the most characteristic and defining aspect of this tradition (Figure 11). CCR is almost unique to TMD and surrounding sites and was long a source of puzzlement for the West Africanist ceramicist community. Initially it was thought that it could be another form of mat or net impression, until Alexandre Livingstone Smith (pers. comm.) confirmed roulette 'repeats' on larger individual sherds at unexpectedly long distances. These are thus unusually thick roulettes (c. $3 \mathrm{~cm}$ ) woven around some form of core (Figure 12). Accompanying cord roulettes which commonly co-occur with CCR include: twisted cord roulette [CR6], cord-wrapped roulettes [CSR], and folded strip roulette [CR4]. The bands of rouletted décor are usually separated with incised channels, which frequently also feature on the lips of vessels. In addition to this, the upper part of the body often features geometric patterns, usually painted and incised, sometimes only one or the other. These patterns are almost exclusively triangular (both 
upright and inverted triangles), often featuring cross-hatching and painted in white, red or black.

As a supplement to the two main traditions, there is one further, much less frequent, type of ware that deserves mention. We term these wares RSO, for 'Red Slip Only'. These vessels are made of a relatively fine paste, and the vessels are inevitably red slipped and highly burnished throughout their exterior and also sometimes on their interior. There is no conclusive evidence as to the forming techniques of these wares, though some of the smaller examples appear to be drawn from a hollowed lump of clay (see also Keita 2011, 169). The vessels of this type are sometimes decorated with horizontal bands of multiple incised channels and can feature pedestal or tripod footed bases (see Bedaux 1980).

\subsection{Temporal trends in the pottery assemblage:}

Using combined data from Units A, B, and C, we can observe the temporal development of the pottery assemblage at TMD (Figures 13 and 14). As can be seen in Figure 13, the exclusive attributes of Traditions A and B (MAT and CCR respectively), coexist throughout the sequence. But while Tradition B remains stable in its prevalence, Tradition A is significantly more common in the two earliest horizons. RSO wares also seem to decrease through time. Clearly increasing towards the later parts of the site's occupation are twisted cord roulettes (CR6) and multiple parallel incised channels (MCH). PAINT appears common throughout the sequence, in line with the wide ranging fashion for painted wares in the Middle Niger c. AD 400-900, first revealed in the pottery sequence of Jenné-jeno (McIntosh 1995)

The development of rim forms (Figure 14) shows that the main types of everted (E1, E4-6) and simple (S1-3) rims persist throughout the sequence, while less prevalent forms, appear to 
be more temporally specific. E7 and E11, for instance, appear to be unique to first half of the sequence, while the latter half sees the introduction of some new forms: E8, E9, S4 and S5.

Overall, the assemblage from TMD is remarkably stable over more than six centuries. This is not unprecedented in the Middle Niger and surrounding areas, where complexes of decoration, technique and form may change little over the best part of 500+ year phases (e.g. the Jenne-jeno assemblages, McIntosh 1995).

\subsection{TMD ceramics in wider context}

TMD's ceramic traditions appear to represent a clean break from those of the local Ceramic LSA (see MacDonald 1996), thus suggesting the transformation or replacement of local populations sometime between $500 \mathrm{BC}$ and $\mathrm{AD} 500$. However, there appear to be connections with more contemporary ceramic traditions. TMD Tradition A bears a close resemblance to the later historic and contemporary pottery of the Bandiagara escarpment (Tradition Dogon A and B, Gallay et al. 1998). Intriguingly, this suggests a far deeper time depth to styles of pottery considered typically 'Dogon' than has been generally claimed for Dogon populations themselves (see also Mayor et al. 2005). Likewise TMD Tradition B pottery shares some design aspects with the contemporary Songhai pottery of the Lakes region, notably a frequent usage of painted, internally hatched triangles on collared jars (e.g. Gallay et al. 1996: 103). However it would be a mistake to project ethnic connections between these archaeological and recent historic traditions. Rather, it would be more useful to think of geographic centres of gravity for certain practices and motifs, which may endure via matrilineal potting traditions despite circumstances causing populations to accept new waves of socio-political dominance or other forms of acculturation, including linguistic shifts. In other words, without wishing to digress too far, one may hazard that the relatively recent Dogon and Songhai ethnic identities of the Dyoundé/Bandiagara and Lakes region have over-printed substantial enduring elements 
of local populations and traditions.

Statistical comparisons with other first millennium AD pottery assemblages across the wider region allow us to define areas of similar decorative expression for TMD Traditions A and B. Correspondence analysis using the percentages of main decorative attributes from wellpublished datasets across the wider region show that clear statistical differences exist between the sites on the Bandiagara escarpment to the south of TMD, the Gourma/Oudalan to the East, and the different areas of the Middle Niger to the West (Figure 15; see Gestrich 2013 for a full description of this analysis). When plotted amongst these other assemblages, TMD's Tradition B clearly clusters with the assemblages from the Lakes region and the Eastern IND, whereas Tradition A is most closely related to the Gourma/Oudalan group. This suggests that the producers of the pottery types drew their cultural influences from two separate geographical spheres, indicating that the Douentza area was a cultural crossroads in the first millennium AD, just as it is today. Moreover, the pull of the Middle Niger sphere on Tradition B pottery suggests that TMD entertained closer links to the western areas putatively under the control of the Ghana Empire that to those controlled by Kawkaw, to the east, to whose firstmillennium AD pottery TMD ceramics bear little resemblance (Cissé 2011). It is also notable that, while not part of the statistical analysis, RSO wares have their closest parallels in some of the pottery recovered from the excavations of the Lakes Region tumuli at El Oualadji and Killi (Lebeuf \& Pâques 1970; Desplagnes 1903).

A main goal of the 2010 excavation was to test whether or not Traditions A and B represented two different groups cohabiting at the site. From the 2010 excavated sample, however, it appears that the distribution of the pottery types does not mark clear social boundaries at TMD. Indeed, a mixture of both was present in all excavated spaces. Throughout the different areas of eleventh century abandonment surfaces excavated, the pottery traditions occur in 
proportions of roughly two parts of Tradition B sherds to one part Tradition A sherds. The same approximate proportions were also observed in surface collections of habitation sites recorded during the regional survey. The stability of this distribution pattern suggests that the social boundaries visible in the pottery at the production stage are not relevant to the behaviour of the consumers of the pottery who appear to have used pots from both traditions indiscriminately.

It is, of course, not secure to make such inferences from the finds of pottery fragments alone, as the processes leading to their deposition in the different areas of the site are far from secure. With the 49 intact and complete pots excavated at TMD, on the other hand, we have certain primary depositional contexts. In the vast majority of cases, the pots were found turned upside down. The frequency of this type of deposition on the floors of houses is conspicuous, and may point to a ritual associated with the letting up of buildings. In 2010 , keeping an upturned pot on the roof of the house, usually covering some form of medicine, was still a common practice in Douentza and, while the upturned pots at TMD were never shown to contain anything, we could speculate that perishable materials might have been placed under these pots in a similar way.

In general, the ratio of Tradition A to Tradition B also holds for the intact pots. Amongst the 37 examples recovered from the northern concession (Units A, E, and F), 16 are from Tradition B, 5 from Tradition A, 4 RSO and 5 footed bowls. An interesting exception are the nine vessels from the putative potter's workshop in Horizon 3. Remarkably, five of them have mat impressions, thus belonging to Tradition A while the remaining four pots are all decorated with dragged grasses, paint, and either folded strip roulette, twisted cord roulette or a single-bead cord-wrapped roulette - placing them soundly in Tradition B. This is an interesting finding, for, should our interpretation of a potter's workshop be accurate, this 
would imply that, despite the traditions being visually distinct and remaining this way throughout the sequence, both were utilised or curated even by primary producers of the other tradition. Or, more incredibly, they may have been produced in the same workshops.

\section{Metallurgy and craft specialisation}

One of the most archaeologically eye-catching activities at TMD as well as at surrounding sites is metallurgy. As was noted above, Horizons 3 and 4 contained a delimited area of slag (almost $21 \mathrm{~kg}$ in small fragments) scattered through fine layers of burned earth and ash. This was interpreted as the remains of a blacksmith's workshop. Unit F contained a more substantial building, with associated earthen features which we also interpret as a working area for blacksmiths (Figure 16). Likewise, the surfaces of all habitation sites in the region are covered with small slag fragments and burnt earthen structures that closely resemble those excavated in the TMD Unit F blacksmith's workshop. This evidence for intense metallurgical activity is not restricted to certain specific areas of sites or individual sites within a cluster as in other areas of the Middle Niger (e.g. Bedaux et al. 1978; McIntosh 1995; Bedaux et al. 2001; Schmidt 2005). Indeed, the evidence is so dense that it seems as though iron metallurgy was being practised in virtually every compound of these settlements.

The slag fragments found at TMD appear to be the remains of smithing activities, turning iron blooms into bars or finished implements, as indicated by its chemical analysis which showed elevated levels of lime, iron metal prills and plano-convex shapes typical of smithing slags (Humphris 2013). From Humphris' analysis there are also indications that two forms of smithing were taking place at the site - one preliminary stage to refine the blooms into workable iron, and a second stage in which finished implements were made (ibid.). 
The actual smelting of iron appears to have usually taken place away from the habitation sites. The sites of Tangu 2 and Boata (Figure 8) are furnace fields with mounds of slag and tuyeres piled up around what appear to have been repeatedly used furnaces. The northern part of the Boata field, excavated during the 1996 season, returned an AMS date of 251-620 cal AD at one standard deviation (GX-21726), making it coeval with the beginning of TMD's occupation (Woodhouse n.d). A shift in technology observable at the site, from low shaft bowl furnaces in northern part (such as the example excavated) to tapping furnaces in the later southern part indicates that the furnace field was operated over a significant length of time.

The analysis of smelting slags shows that, after an initial experimentation with comparatively inefficient bowl furnaces, the later slag tapping furnaces at Boata south, Tangu 2 and N'gassa were operated with skill in an optimum environment for extracting the most possible iron from the ore (Woodhouse n.d.; Humphris 2013). Slag samples across these sites are very similar in chemical composition, indicating that the processes necessary for a successful smelt were well known and could be reproduced time after time. These furnaces would have required a significant amount of manpower to operate, but could produce large amounts of bloom in single, long smelting episodes.

Iron metallurgy thus seems to have taken place in a combination of community co-operation for the smelting of ore, to individual domestic craft work for the later stages of iron working in the forge. Contrary to expectations gained from ethnographic and historical accounts, metalwork does not appear to have been a specialised activity locally, but rather a feature of most compounds at TMD and the surrounding sites. This is significant, as the economic and social segregation of blacksmiths from other members of society is a fundamental feature of social organisation in large parts of West Africa (McNaughton 1988; Tamari 1991, 1995; 
Kanté 1993). Neighbouring areas may well have had such a segregated form of metallurgical specialists during the first millennium AD, as has been documented at Jenné-jeno (McIntosh \& McIntosh 1980; McIntosh 1998, 2005) and Dia (Schmidt 2005), where only one or a small number of mounds show significant accumulations of metalworking remains, while others remain free of them. The latter phenomenon is comparable to the numudugu, or separate blacksmith's settlements of modern-day Mali (Walicka Zeh 2000). The organisation of blacksmith settlements in the Douentza area, along with evidence for subsistence millet farming (Capezza n.d; Uebel n.d;see above), might suggest that the ethnographically and historically known division between farmers and smiths was not present at TMD. Instead of the caste-based separation that traditionally provides rigid structure to Mandé society, other factors must have structured craft production at TMD and its region during the first millennium $\mathrm{AD}$.

While the inhabitants of TMD and its neighbouring settlements surely retained a status as specialist craftspeople, this specialisation is at a different scale than that known from the IND and ethnographic examples, and reflects a growing body of evidence of intensive iron production in ancient Mali. Finds in the Méma region, north-west of the Inland Niger Delta, the Lakes region to the north, and the Dogon country to the south-east have also indicated the existence of large-scale smelting operations (Håland 1980; Togola 2008; Chieze 1991; Serneels \& Perret 2003; Robion-Brunner 2010). Certainly, the production at and around TMD exceeds local needs, as is indicated by the fact that TMD has by far the highest ratio of slag to excavated sediment for any excavated habitation site in Mali $(414 \mathrm{~g} / \mathrm{m} 3$, as compared to 147 $\mathrm{g} / \mathrm{m} 3$ at Jenne-jeno with the next highest ratio). Rather, it looks as though the metallugical activity on these sites constitutes a form of proto-industrial production, geared towards regional trade, which has already been suggested for sites in the Méma (Håland 1980) and the 
Dogon country (Vincent Serneels, pers.comm.). The primary smithing stage at TMD might correspond to the manufacturing of rough iron bars for trade (Humphris 2013).

The unequal distribution of necessary resources for iron production across the Middle Niger would have ensured markets for such produce. The absence of suitable iron ore in the heavily populated IND is certain to have made many thousands of farmers in this most fertile part of the region dependent on imported iron. Indeed, a shift in the way that Jenne-jeno was provisioned with iron can be seen in the fourth century, after which there is no more evidence for local smelting, though smithing activities appear to continue (McIntosh 1995). Håland (1980) has suggested that the task of provisioning the populous IND with iron could have been a decisive factor in the development of large-scale polities and social complexity in the Middle Niger. Might not the organizing forces of a polity have been likely to have dispatched specialists to suitable areas to undertake such critical production? Such state-ordered landscapes of production are well documented in the $18^{\text {th }}-19^{\text {th }}$ century empire of Segou (MacDonald and Camara 2012). Might this not also have been possible in earlier periods?

The trade in iron must have been high in volume, and was very likely institutionalised in order to ensure supply (McIntosh 2005: 147). Lovejoy (1985) supposes that international trade is largely responsible for the development of trading specialists and institutions, but that a trade of raw iron, salt, stone, including perishables such as kola nuts in large quantities would have required some organization of primary production. While such a trade could have been nurtured through a complex heterarchical system, as RJ McIntosh (1998) has suggested, there is also ample evidence for the active involvement of pre-colonial West African polities in economic affairs (MacDonald \& Camara 2011; Azarya 1997). The need for a secure supply of certain commodities could well have been an important motivation in the increasing political power and the expansionist interests of the Empire of Ghana during the first millennium, as it 
was in those of the Songhay Empire in the mid-second millennium AD (Lovejoy 1985). We must therefore consider the possibility that the iron production around TMD, and maybe the whole existence of the settlements there, was intimately tied to planned enterprises at a macro-regional scale, part of a state-organised economic landscape. Changes to the political and economic organisation of the wider region that accompanied the decline of the Empire of Ghana might then help to explain the TMD's rapid abandonment in the 12th century.

\section{Conclusions}

Due to the excellent preservation at TMD, the site has enabled us to pose questions which have not been as easy to address elsewhere in the Middle Niger, where architectural remains are usually in a far more degraded state. At TMD, the preservation of architectural remains, and a clear sequence of such remains, has allowed an interpretation of continuity and change in the living arrangements of the population. The architectural sequence shows us a modular form of building in which rooms and building could be added and changed according to their user's wishes, but it also shows how durable boundaries and foundation lines within built environment were. Two distinct living areas separated by a pathway, and several structures, are upheld in every rebuilding event over 500 years. We argue that these two primary architectural divisions represent durable social boundaries which divided this part of the settlement into kinship-based cohabiting groups comparable to lineage compounds we know from the present day. Further development of this hypothesis is unfortunately hampered by the fact that settlement plans at a scale which would allow significant spatial analysis at settlement scale are beyond the logistics, budgets and security constraints for Malian archaeology in the foreseeable future. This is a fundamental problem in our understanding of urbanism and settlement in the ancient Middle Niger. While our excavations represent a promising attempt at answering such questions via excavation, it is clear that a much larger 
sample is necessary to make really meaningful statements. We can only hope that advances in non-invasive techniques might someday get us there - at least at the level of abandonment surfaces.

Within these compounds, the well-preserved and contextualised artefactual and organic remains have allowed us to explore a number of themes regarding the domestic economy, ritual life and craft production. The evidence points to an agricultural community, or at least one that lived in an heavily agricultural landscape. Millet was a staple grain, ovicaprids, cattle, chickens, and dogs were raised at or around the site. Fruits such as those of Ziziphus sp. were gathered, and game of various sizes was hunted, though the population relied far more heavily on domestic species. Stone grinding implements and basins evidence the processing of grains in and around the buildings. The settlement pattern of the area also speaks to this rural theme, its single nucleated sites being at clear variance to the clustered settlements of the urban IND.

As the ceramic analysis has demonstrated, there is a clear co-existence of two technically and visually distinctive pottery traditions at the site, which appear to stem from different cultural spheres. We cannot be certain whether these distinctions were present at the site itself, since the discard pattern of the ceramics appears to show that people used vessels of both traditions indiscriminately. However, we suggest that their long-term coexistence shows that the rural area around TMD was not only at the margins of the core political regions of Ghana/Wagadu and Kawkaw, but also that it was also at the cross-roads of different spheres of cultural influence.

In addition to this picture of a largely self-supporting agricultural population, there is also ample evidence for specialisation at TMD. Within the domestic compounds, we found 
contexts that clearly relate to the working of iron, and likely also to the production of pottery. One of the most dramatic results of the excavations and surveys is the proto-industrial scale at which iron was produced. This stands in stark contrast to contemporary evidence from the IND, where metallurgists appear to have been a small minority, and spatially clearly separated from the remaining population.

The ironworkers of TMD and neighbouring sites were specialists in a larger regional context. The amount of iron produced at TMD and local contemporary sites would have gone far beyond the needs of their area's populations. It is likely that these blacksmiths were supplying iron to a sophisticated wider Middle Niger trade network. Such trade linked the flourishing cities and fertile agricultural lands of the IND with more peripheral areas, such as those producing salt in the Sahara, quarrying sandstone along escarpments, or producing iron, and allowed other goods to pass into these peripheries. At TMD, imported items included ornamental goods such carnelian, ostrich egg-shell and granite beads, but also food resources such as cattle and dried fish.

Regional trade networks for vital goods were fundamental to the socio-political development of the Middle Niger region during the first millennium AD, and may well have been driving factors in the growth of urban centres and the establishment of large-scale polities. In the case of TMD, the Empire of Ghana, which provided political integration on an unprecedented scale for the region, may well have had an influence on settling specialists in the region. As such, we can see an important motor of social complexity in the occupation of such seemingly peripheral sites. TMD was an integral part of a complex, supra-regional system of specialised production and high-volume trade. TMD's rural ironworkers were thus an essential part in the inner workings of a diverse and complex Middle Niger civilisation. 


\section{Acknowledgements}

Gestrich's work presented in this paper was funded by the Royal Anthropological Institute's Emslie Horniman Scholarship, the UCL Institute of Archaeology and the Tweedie Exploration Fellowship.

MacDonald's research presented here was funded by The Prehistoric Society, the British Academy and the Arts and Humanities Research Council (UK). The authors would like to thank the Malian Institut des Sciences Humaines, Kléna Sanogo, Daouda Keita, Sekou Berté, Jay Woodhouse, Cecilia Capezza, Yamoussa Fané and Soumaila Coulibaly for their research cooperation in the various field seasons of this project. Both authors also thank their excavation teams in Douentza, particularly Amadou Dolo, Tangis Tangara and Baba Coulibaly. 


\section{Notes on Contributors}

Nikolas Gestrich is a "Freigeist" Fellow, funded by the VW Foundation, at the Frobenius Institute in Frankfurt. His main research interests lie in the archaeology of West Africa, especially its political formations and social complexity. He is currently involved in research projects in the Segou region of Mali.

Kevin MacDonald is Professor of African Archaeology and Programme Chair of African Studies at University College London. He has worked in Mali since 1989 and specialises in African historical archaeology, including issues of slavery and ethnicity. His ongoing field research focuses on the Segou region from the $13^{\text {th }}$ through the $19^{\text {th }}$ centuries. 


\section{Bibiliographical References}

Azarya, V. 1997. Economic Enterprise in Fulbe and Mande States: Maasina and Samori. In: de Bruijn, M. \& van Dijk, H. (eds.), Peuls et Mandingues. Dialectique des constructions identitaires. Karthala, Paris, 61-84.

Bedaux, R. M. A. 1980. The Geographic Distribution of Footed Bowls in the Upper and Middle Niger Region. In: Swartz, B. K. \& Dumett, R. (eds.), West African Culture Dynamics: Archaeological and Historical Perspectives. Mouton, Hague, Paris and New York, pp. 247258.

Bedaux, R. M. A., Constandse-Westermann, T. S., Haquebord, L., Lange, A. G. \& van der Vaals, J. D. 1978. Recherches archeologiques dans le Delta Interieur du Niger (Mali). Palaeohistoria Bussum 20, 91-220.

Bedaux, R. M. A., MacDonald, K. C. \& Gallay, A. 2003. L'archéologie des Dogon de l'Est: Nokara, Sarnyére et Douentza. In: Bedaux, R. M. A. \& Van Der Waals, J. D (eds.), Regards sur les Dogon du Mali. Rijksmuseum voor Volkenkunde/Editions Snoeck, Leiden/Ghent, pp. 83-91.

Bedaux, R. M. A., MacDonald, K. C., Person, A., Polet, J., Sanogo, K., Schmidt, A. \& Sidibe, S. 2001. The Dia archaeological project: Rescuing cultural heritage in the Inland Niger Delta (Mali). Antiquity 75 (290), 837-848. 
Blanck, J. P., Pion, J. C., Besnus, I. \& Ballo, A. 1996. Paleoécoulements et paléoenvironnements dans le Gourma lacustre (Mali). Apports des données satellitaires. Préhistoire Anthropologie Méditerranéennes 5, 111-117.

Capezza, C. n.d. The Plant Remains. In: MacDonald, K. (ed.), Final Report on the 1995/1996 Southern Gourma Field Season. Unpublished Report to the British Academy, ref. BAAN1928/APN2336, London, pp. 18-23.

Cashion, G. A. 1982. Hunters of the Mande: a behavioral code and worldview derived from the study of their folklore. Ph.D. Thesis. Indiana University, Bloomington.

Chieze, V. 1991. La Métallurgie du fer dans la zone lacustre. In: Raimbault, M. und Sanogo, K. (eds.), Recherches archéologiques au Mali. Karthala, Paris, 449-472.

Cissé, M. 2011. Archaeological Investigations of Early Trade and Urbanism at Gao Saney (Mali). PhD Thesis. Rice University.

Cissé, Y. 1994. La confrérie des chasseurs Malinké et Bambara: mythes, rites et récits initiatiques. Editions Nouvelles du Sud, Ivry.

Desplagnes, L. 1903. Étude sur les Tumuli du Killi dans la Région de Goundam. L'Anthropologie 14, 151-172. 
Dueppen, S. A. 2011. Early evidence for chickens at Iron Age Kirikongo (c. AD 100-1450), Burkina Faso. Antiquity 85, 142-157.

Duran, L. 2000. Women, music, and the "mystique" of hunters in Mali. In: Monson, I. (ed.), The African diaspora: a musical perspective. Garland Publishing, New York, pp. 137-185.

Gallais, J. 1975. Pasteurs et paysans du Gourma: La condition sahelienne. CNRS, Paris.

Gallay, A., Huysecom, E. \& Mayor, A. 1998. Peuples et ceramiques du delta interieur du Niger (Mali). Un bilan de cinq anees de missions (1988-1993). Phillipp von Zabern, Mainz.

Gallay, A., Huysecom, E., Mayor, A. \& Ceuninck, G. de 1996. Hier et aujourd'huiDes poteries et des femmes : céramiques traditionnelles du Mali. Département d'anthropologie et d'écologie de l'Université, Geneva.

Gestrich, N. 2008. The pottery from Tongo Maaré Diabal (Mali) in its regional, temporal and spatial contexts. Unpublished MA dissertation. UCL, London.

Gestrich, N. 2013. The Archaeology of Social Organisation at Tongo Maaré Diabal. Unpublished Ph.D. Thesis. UCL, London.

Håland, R. 1980. Man's role in the changing habitat of Méma during the old Kingdom of 
Ghana. Norwegian Archaeological Review 13 (1), 31-46.

Hillier, B. \& Hanson, J. 1984. The social logic of space. Cambridge University Press, Cambridge.

Humphris, J. 2013. The Iron Producers of Gandamia: Late $1^{\text {st }}$ millennium AD ferrous metallurgy in the Gourma-des-Monts. In: Gestrich, N., The Archaeology of Social Organisation at Tongo Maaré Diabal. Unpublished Ph.D. Thesis. UCL, London, pp. 211-253.

Huysecom, E., Ozainne, S., Jeanbourquin, C., Mayor, A., Canetti, M., Loukou, S., Chaix, L., Eichhorn, B., Lespez, L., Le Drézen, Y. \& Guindo, N. 2015. Towards a Better Understanding of Sub-Saharan Settlement Mounds before AD 1400The Tells of Sadia on the Seno Plain (Dogon Country, Mali). Journal of African Archaeology 13 (1), 7-38.

Huysecom, E., Ozainne, S., Mayor, A., Jeanbourquin, C., Robion-Brunner, C., Ballouche, A., Chaix, L., Cissé, L., Eichhorn, B., Garnier, A., Guindo, N., Kahlheber, S., Le Drézen, Y., Lespez, L., Loukou, Y.S.B., Sanogo, K., Serneels, V., Soriano, S., Soulignac, R. \& Taïbi, N 2011. Le tell de Sadia en Pays dogon. La treizième année de recherches du programme « Peuplement humain et évolution paléoclimatique en Afrique de l'Ouest ». Jahresbericht SLSA 2010, 101-221.

Kanté, N. 1993. Forgerons d'Afrique Noire. L'Harmattan, Paris. 
Keepax, C. A. 1981. Avian egg-shell from archaeological sites. Journal of Archaeological Science 8 (4), 315-335.

Keita, D. 2011. Le peuplement de la marge orientale du delta intérieur du Niger au premier millénnaire après Jésus Christ. Ph.D. Thesis. Université Paris Ouest Nanterre La Défense, Paris.

Keita, D. 2015. Peuplement humain du delta intérieur du NigerLe peuplement de la marge orientale du delta intérieur du Niger au premier millénaire après Jésus Christ. Presses Académiques Francophones, Saarbrücken.

Lebeuf, A. \& Pâques, V. (eds.) 1970. Archéologie Malienne: Collections Desplagnes. Musée de l'Homme/CNRS, Paris.

Linseele, V. 2003. Cultural Identity and the Consumption of Dogs in Western Africa. In:

O’Day, S. J., van Neer, W. und Ervynck, A. (eds.), Behaviour Behind Bones. The Zooarchaeology of Ritual, Religion, Status and Identity. Oxbow Books, Oxford, pp. 318-326.

Linseele, V. 2007. Archaeofaunal Remains from the Past 400 Years in Sahelian West Africa. Cambridge Monographs in African Archaeology 70. BAR International Series 1658. Archeopress, Oxford.

Lovejoy, P. E. 1985. The internal trade of West Africa to 1800. In: Ajayi, J. \& Crowder, M. 
(eds.), History of West Africa 1. Third Edition. Longman, New York, pp. 648-690.

MacDonald, K. C. n.d. Final Report on the 1995/1996 Southern Gourma Field Season. Unpublished Report to the British Academy.

MacDonald, K. C. 1992. The domestic chicken (Gallus gallus) in sub-Saharan Africa: A background to its introduction and its osteological differentiation from indigenous fowls (Numidinae and Francolinus sp.). Journal of Archaeological Science 19 (3), 303-318.

MacDonald, K. C. 1994. Socio-economic Diversity and the Origin of Cultural Complexity along the Middle Niger (2000BC to AD 300). Unpublished Ph.D. Thesis. University of Cambridge, Cambridge.

MacDonald, K. C. 1995. Why Chickens? The Centrality of the Domestic Fowl in West African Ritual and Magic. MASCA Research Papers in Science and Archaeology 12, 50-56.

MacDonald, K. C. 1996. The Windé Koroji Complex: Evidence for the peopling of the eastern Inland Niger Delta. Préhistoire Anthropologie Méditerranéennes 5, 147-165.

MacDonald, K. C. 1997/98. More forgotten tells of Mali: an archaeologist's journey from here to Timbuktu. Archaeology International 1, 40-42.

MacDonald, K. C. \& Camara, S. 2011. Segou: Warfare and the Origins of a State of Slavery. 
In: Lane, P. \& MacDonald, K. C. (eds.), Slavery in Africa. Archaeology and Memory. Proceedings of the British Academy 168, London, pp. 25-46.

MacDonald, K. C. \& Camara, S. 2012. Segou, Slavery and Sifinso. In: Monroe, J. C. \& Ogundiran, A. (eds.), Power and Landscape in Atlantic West Africa: Archaeological Perspectives. Cambridge University Press, Cambridge, pp. 169-190.

MacDonald, K. C. \& MacDonald, R. H. 2000. The origins and develoment of domesticated animals in arid West Africa. In: Blench, R. \& MacDonald, K. C. (eds.), The origins and development of African livestock: archaeology, genetics, linguistics and ethnography. UCL Press, London, pp. 127-162.

MacDonald, K. C., Togola, T., MacDonald, R. H. \& Capezza, C. 1994. Douentza. Past 17, $12-14$.

Mayor, A., Huysecom, E., Gallay, A., Rasse, M. \& Ballouche, A. 2005. Population dynamics and Paleoclimate over the past 3000 years in the Dogon Country, Mali. Journal of Anthropological Archaeology 24 (1), 25-61.

McIntosh, R. J. 1991. Early Urban Clusters in China and Africa: The Arbitration of Social Ambiguity. Journal of Field Archaeology 18 (2), 199-212.

McIntosh, R. J. 1998. The peoples of the Middle Niger: The island of gold. Blackwell 
Publishers, London.

McIntosh, R. J. 2005. Ancient Middle Niger. Urbanism and the Self-Organising Landscape. Cambridge University Press, Cambridge.

McIntosh, S. K. (ed.) 1995. Excavations at Jenne-Jeno, Hambarketolo and Kaniana (Inland Niger Delta, Mali), the 1981 Season. University of California Press, Los Angeles.

McIntosh, S. K. \& McIntosh, R. J. 1980. Prehistoric Investigations in the Region of Jenne, Mali. BAR, Oxford.

McNaughton, P. R. 1988. The Mande Blacksmiths: Knowledge, Power, and Art in West Africa. Indiana University Press, Bloomington.

Osborn, D. \& Helmy, I. 1980. The contemporary land mammals of Egypt (including Sinai). The Field Museum of Natural History, Fieldiana (Zoology) 5. Chicago.

Robion-Brunner, C. 2010. Forgerons et sidérurgie en pays dogon. Africa Magna, Frankfurt.

Schmidt, A. 2005. Reconaissance des alentours de Dia. In: Bedaux, R. M. A., Polet, J., Sanogo, K. \& Schmidt, A. (eds.), Recherches archéologiques a Dia dans le Delta intérieur du Niger (Mali): bilan des saisons de fouilles 1998-2003. CNWS, Leiden, pp. 401-422. 
Schönwetter, M. 1967. Handbuch der Oologie. Volume I. Akademie, Berlin.

Serneels, V.\& Perret, S. 2003. Quantification of smithing activities based on the investigation of slag and other material remains. In: Archaeometallurgy in Europe. Proceedings of the International Conference (Milano, September 24-26, 2003). Associazone Italiana di Metallurgia, Milano, 469-478.

Tamari, T. 1991. The Development of Caste Systems in West Africa. The Journal of African History 32 (2), 221-250.

Tamari, T. 1995. Linguistic Evidence for the History of West African "Castes". In: Conrad, D. C. \& Frank, B. E. (eds.), Status and Identity in West Africa. Indiana University Press, Bloomington, pp. 61-85.

Togola, T. 2008. Archaeological Investigations of Iron Age Sites in the Mema Region, Mali (West Africa). Cambridge Monographs in African Archaeology 73, BAR International.

Uebel, D. n.d.. The charcoal record of the site Tongo Maaré Diabal (Mali). Unpublished report. UCL Institute of Archaeology.

van Neer, W. \& Boucoum, H. 1991. Etude archéozoologique de Tulel-Fobo, site protohistorique (IVe-Xe siècle) de la moyenne vallée du Fleuve Sénégal (République du Sénégal). Archaeozoologia 4, 93-114. 
Walicka Zeh, R. A. 2000. Building practice and cultural space amongst the Bambara, Senufo and Bozo of Mali. An ethnoarchaeological study. Unpublished Ph.D. Thesis. University of London, London.

Walicka Zeh, R. A. \& MacDonald, K. 2004. An ethnoarchaeological study of architectural remains and spatial organisation, an example from the site of Tongo Maaré Diabal, Mali. In: Sanogo, K. \& Togola, T. (eds.), Proceedings of the $11^{\text {th }}$ Congress of the PanAfrican Association for Prehistory and Related Fields. Institut des Sciences Humaines, Bamako.

Wickens, G. E. 1969. A Study of Acacia albida Del. (Mimosoideae). Kew Bulletin 23 (2), $181-202$.

Woodhouse, J. n.d. Boata Furnace, Gourma, Mali. In: MacDonald, K. (ed.), Final Report on the 1995/1996 Southern Gourma Field Season. Unpublished Report to the British Academy, ref. BA-AN1928/APN2336, London, 9-18. 


\section{Figures:}

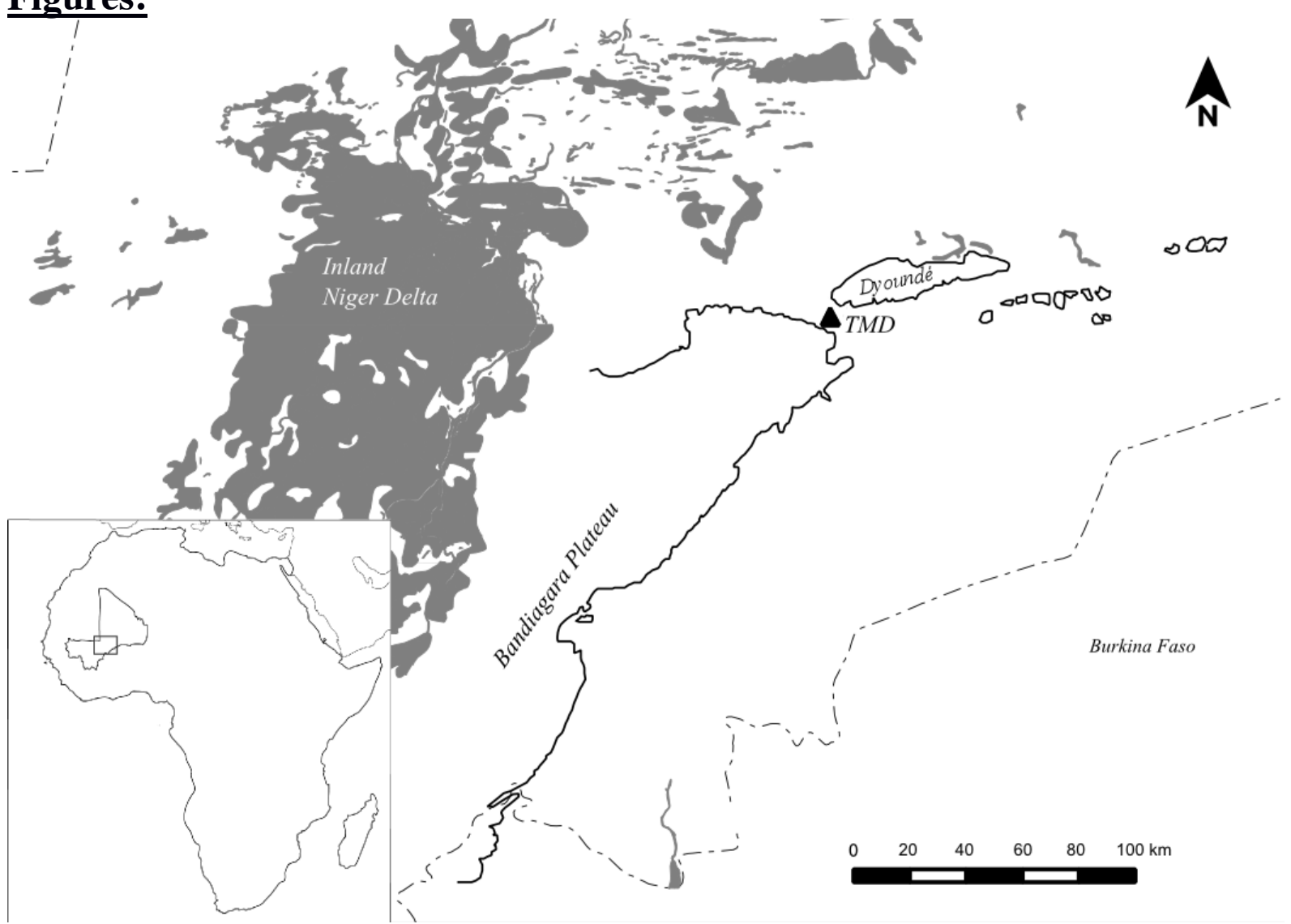

Figure 1: The location of Tongo Maaré Diabal at the edge of the western Gourma.

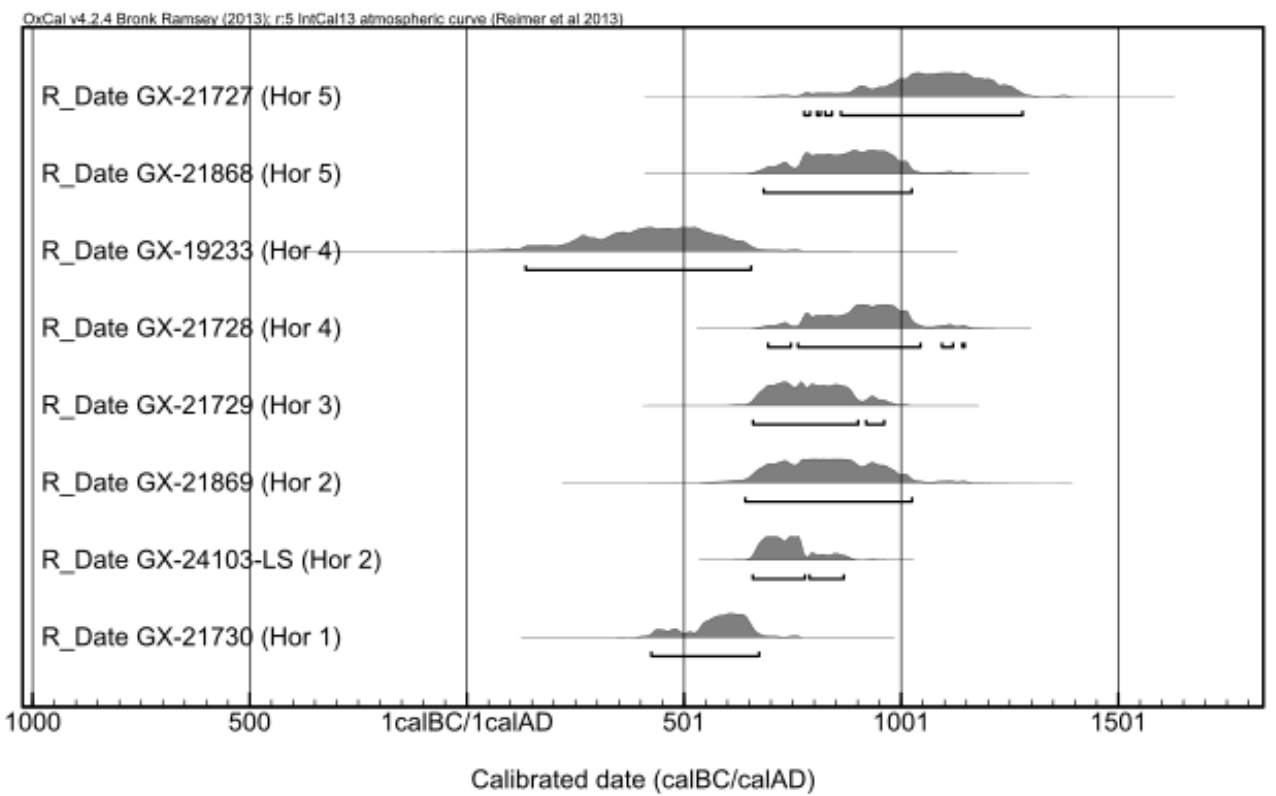

Figure 2: Radiocarbon dates from TMD Units A and B 


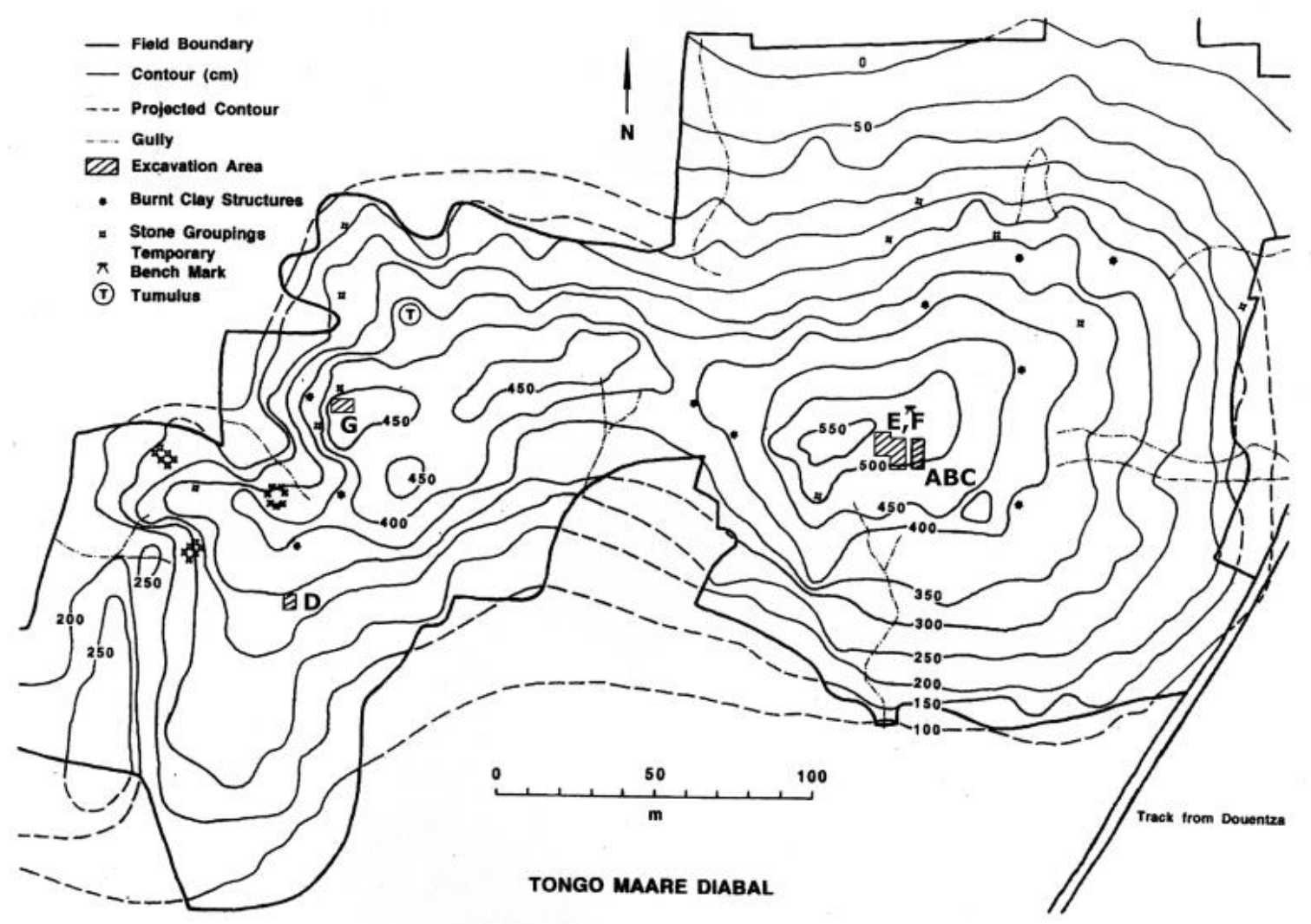

Figure 3: Topographic map of TMD showing the location of the seven excavation units and major surface features. 
Horizon 1

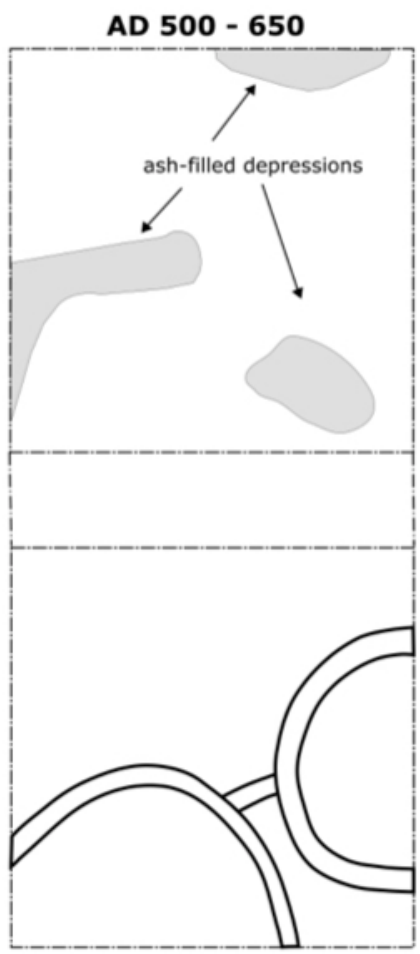

Horizon 2

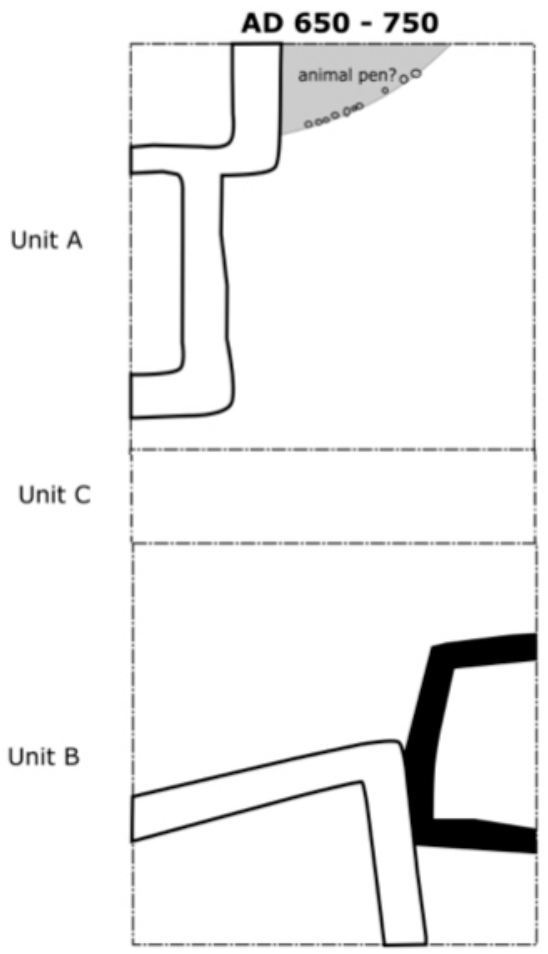

Horizon 3 lower

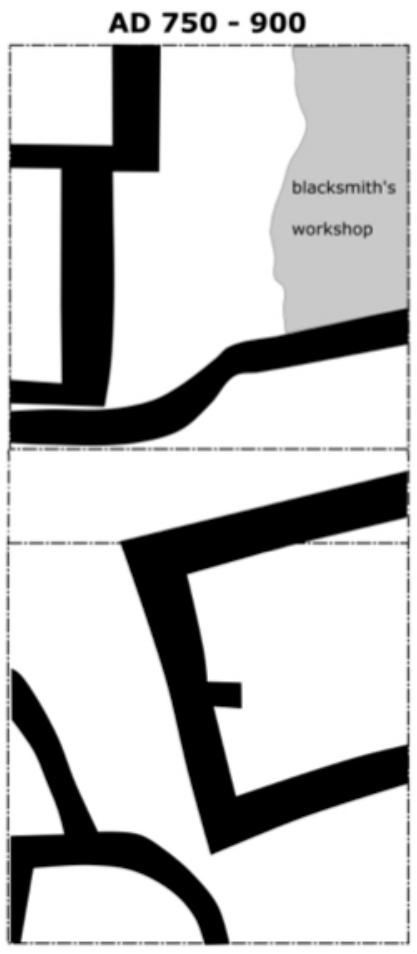

Horizon 3 upper

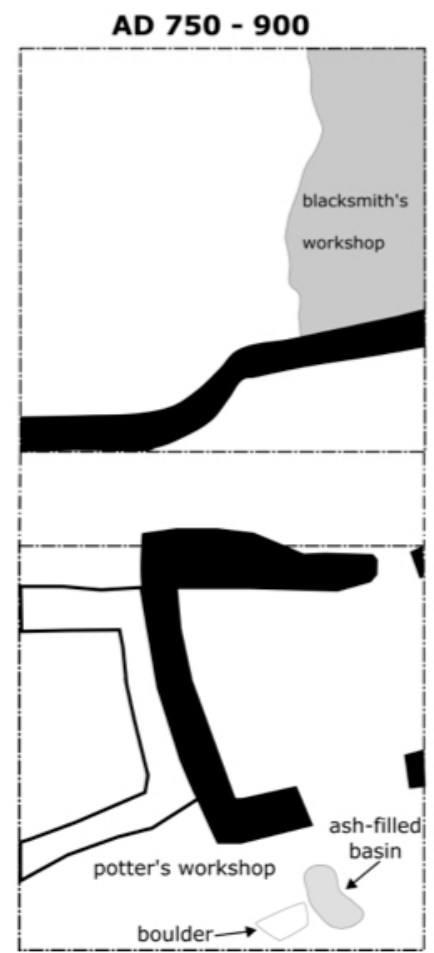

Horizon 4

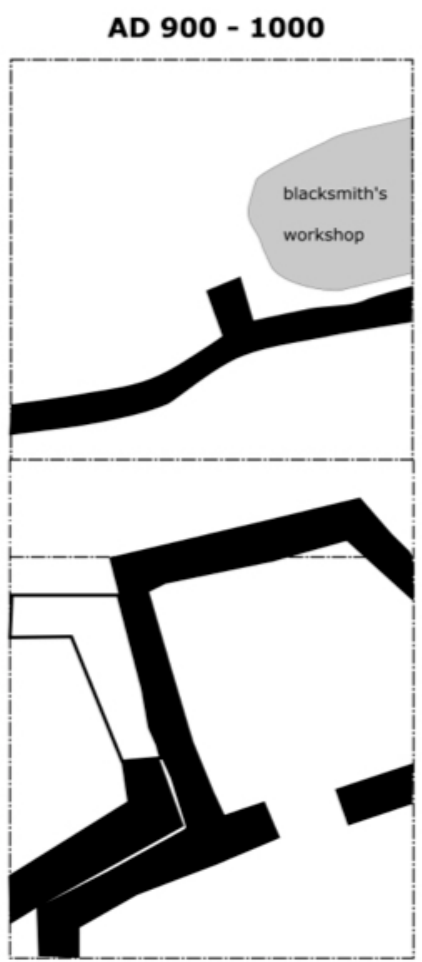

Mud brick

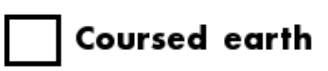

Coursed earth

Horizon 5

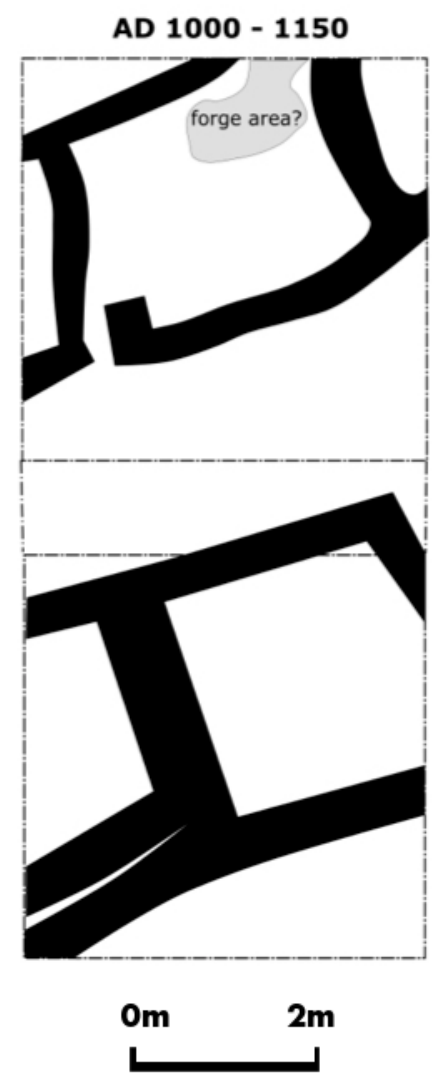

Figure 4: The architectural sequence in units A, B and C 


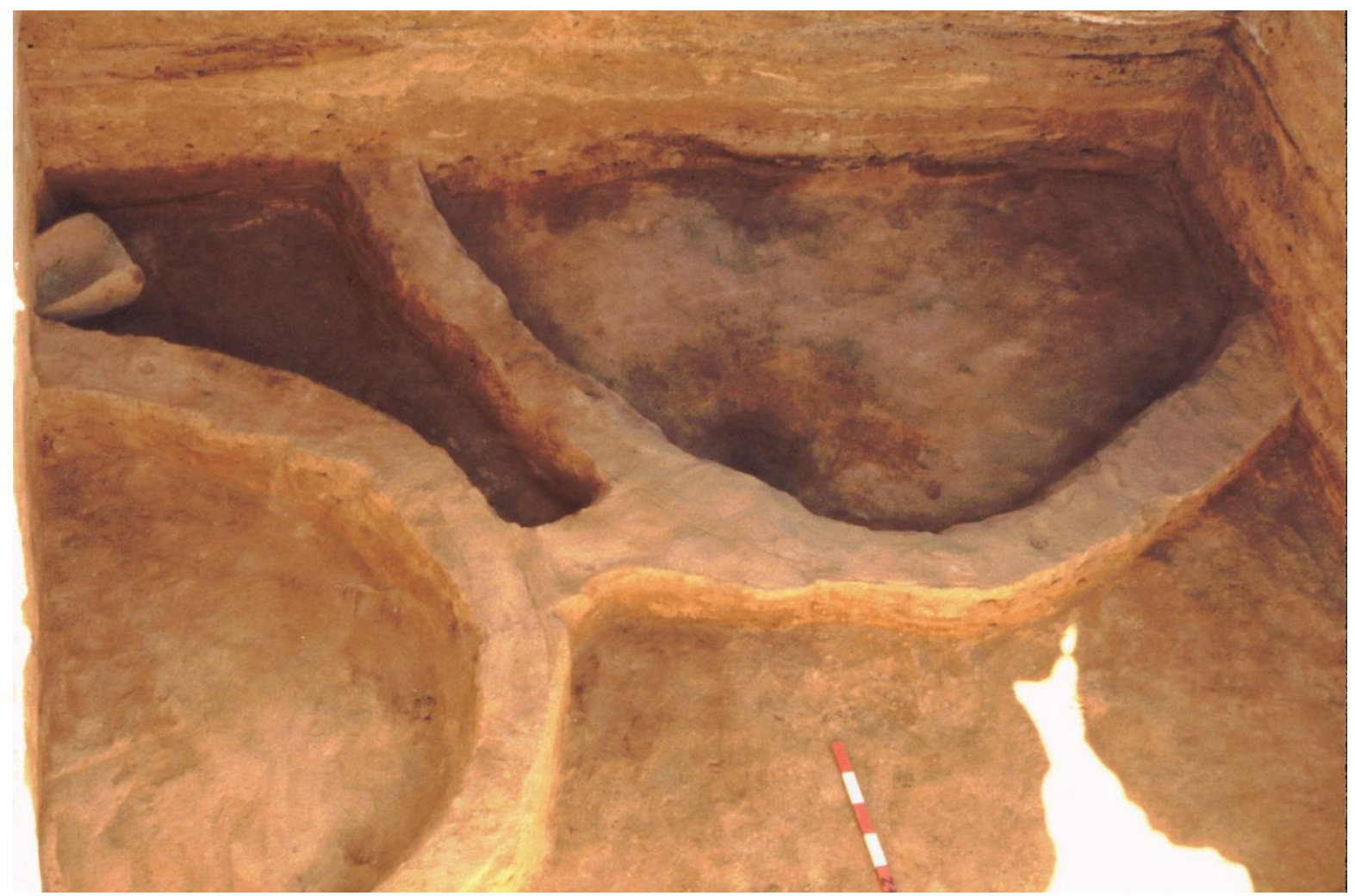

Figure 5: Photo of Buildings in Horizon 1, Unit B. Note stone grinding basin between the two structures.

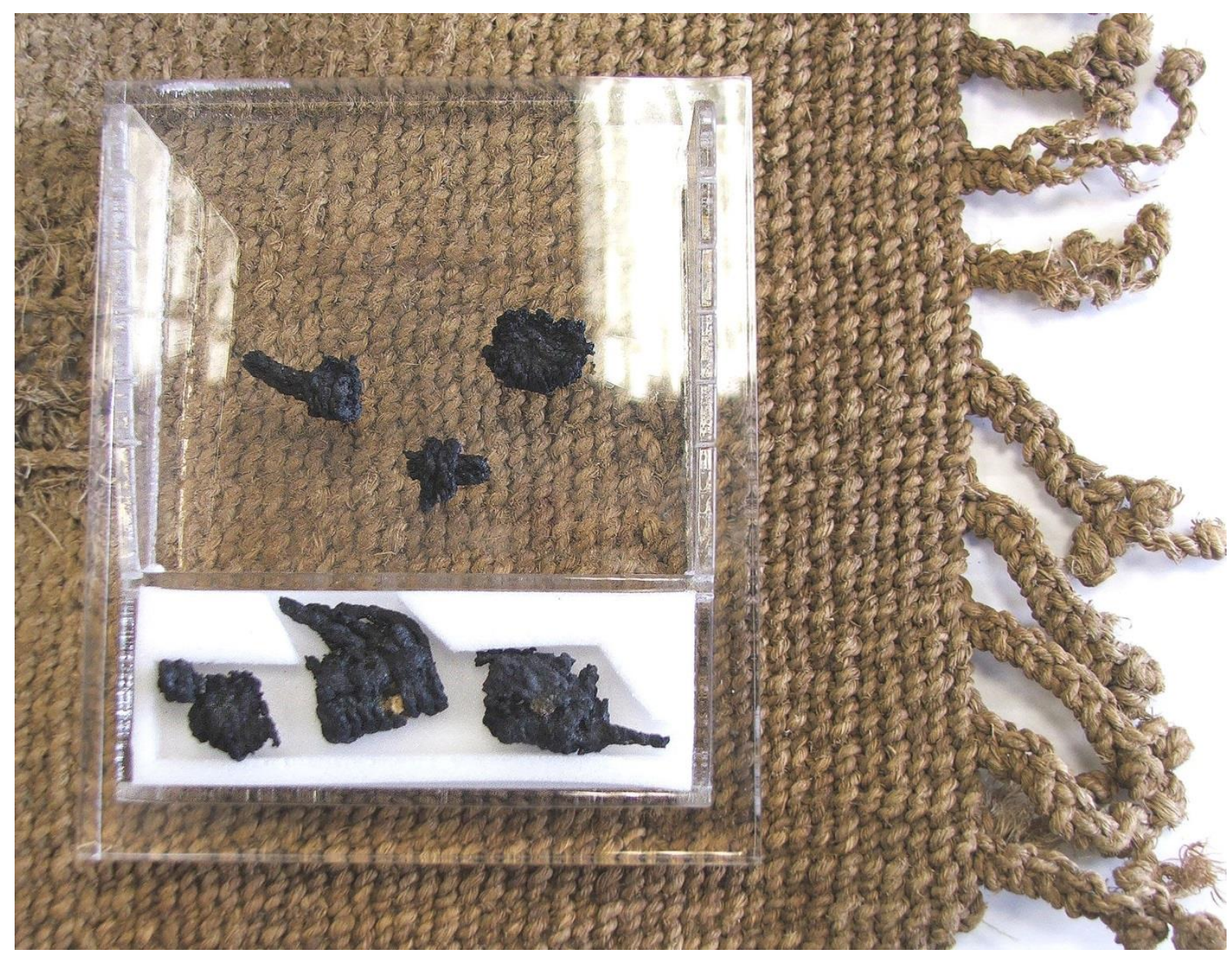

Figure 6: Charred woven hibiscus fibres from Unit B context 66 (Horizon 3), directly dated to 690-890 cal AD

(1235 $\pm 70 \mathrm{bp} ;$ GX-21729). Photographed together with a modern potter's mat from the area, made from baobab fibres with a similar weave. 


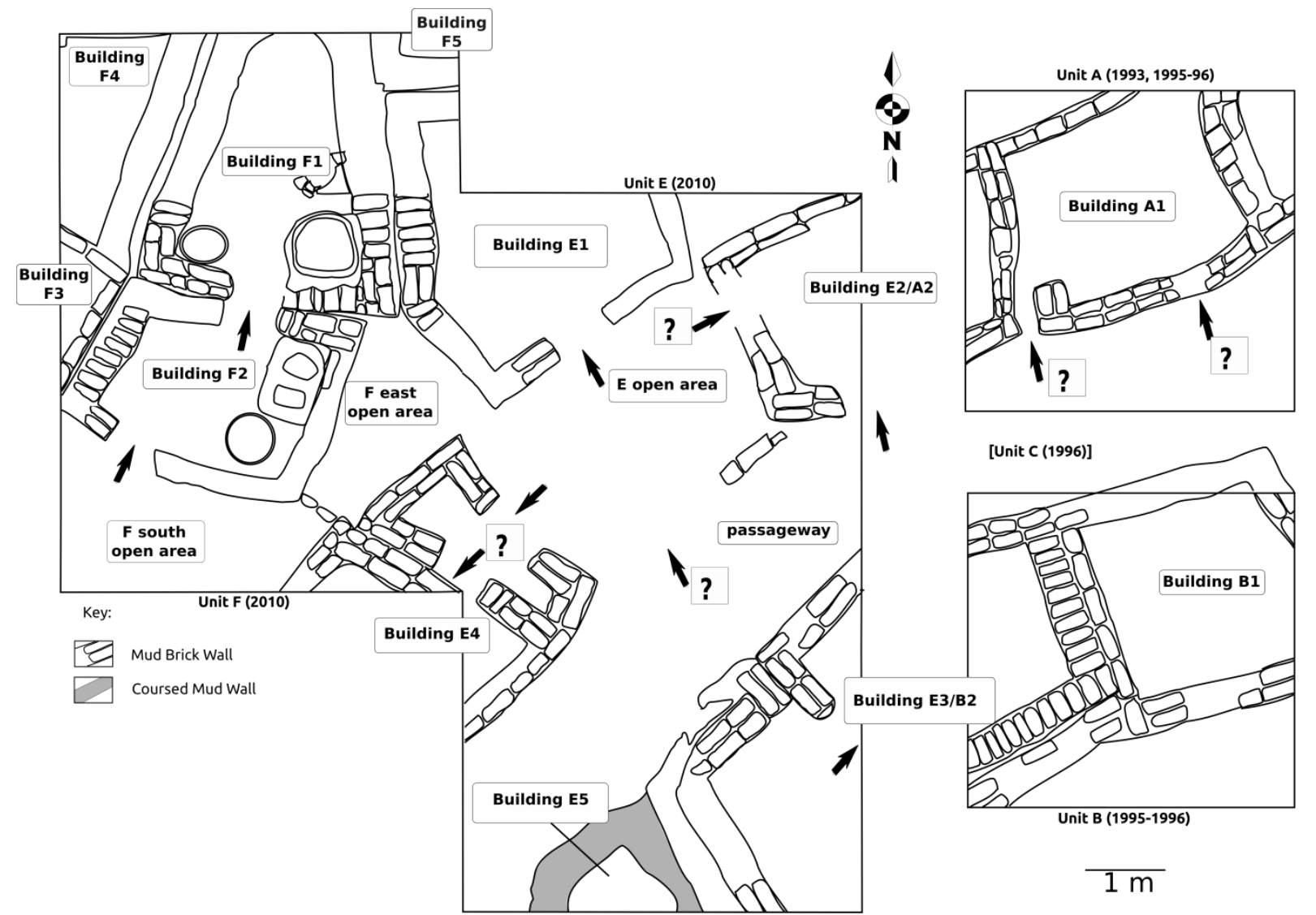

Figure 7: Plan of horizon 5 (c. AD 1000-1150) in Exposure 1 (units A,B,C,E, and F)

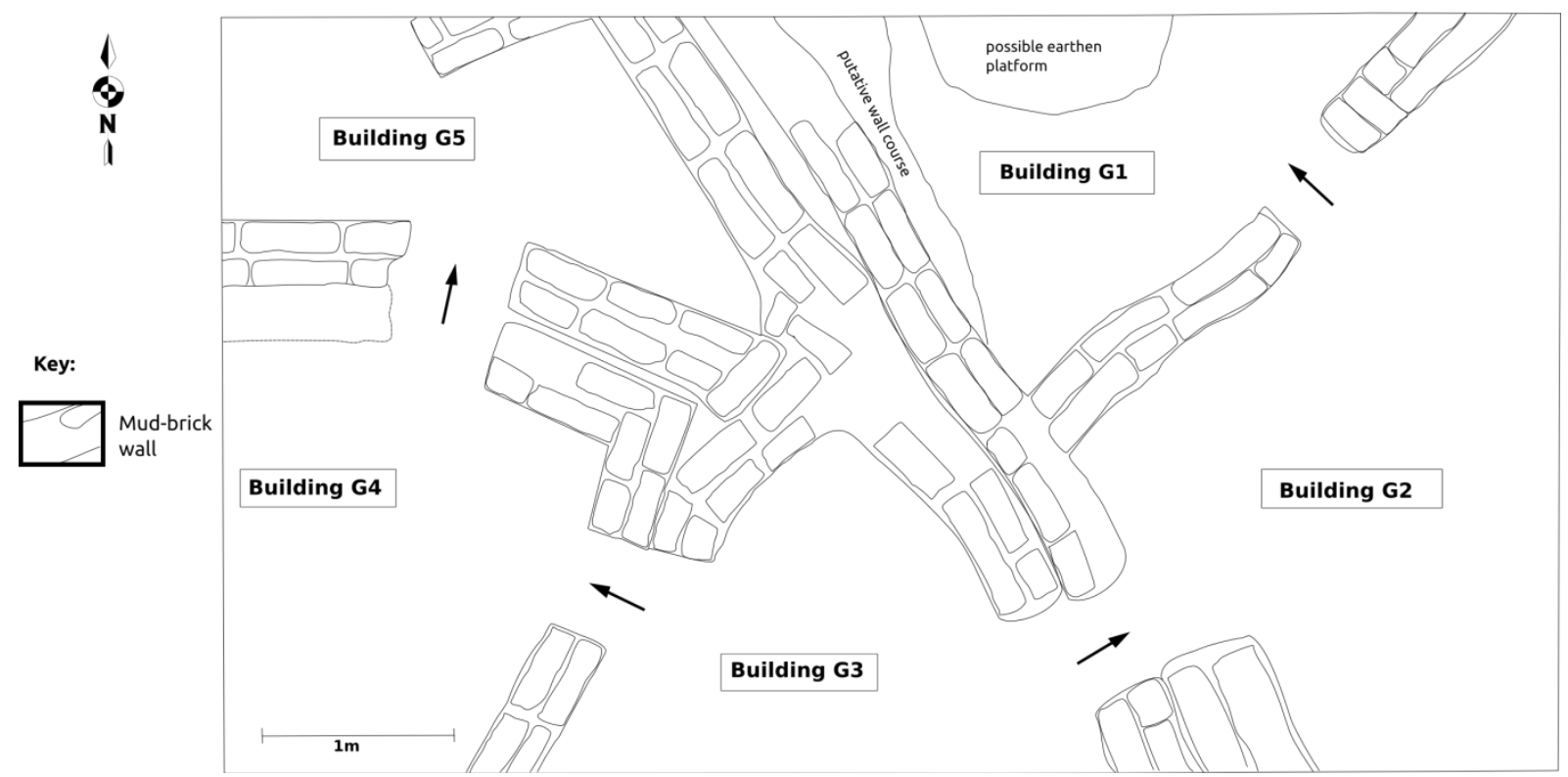

Figure 8: Plan of Exposure 2 (Unit G, 2010 season) 


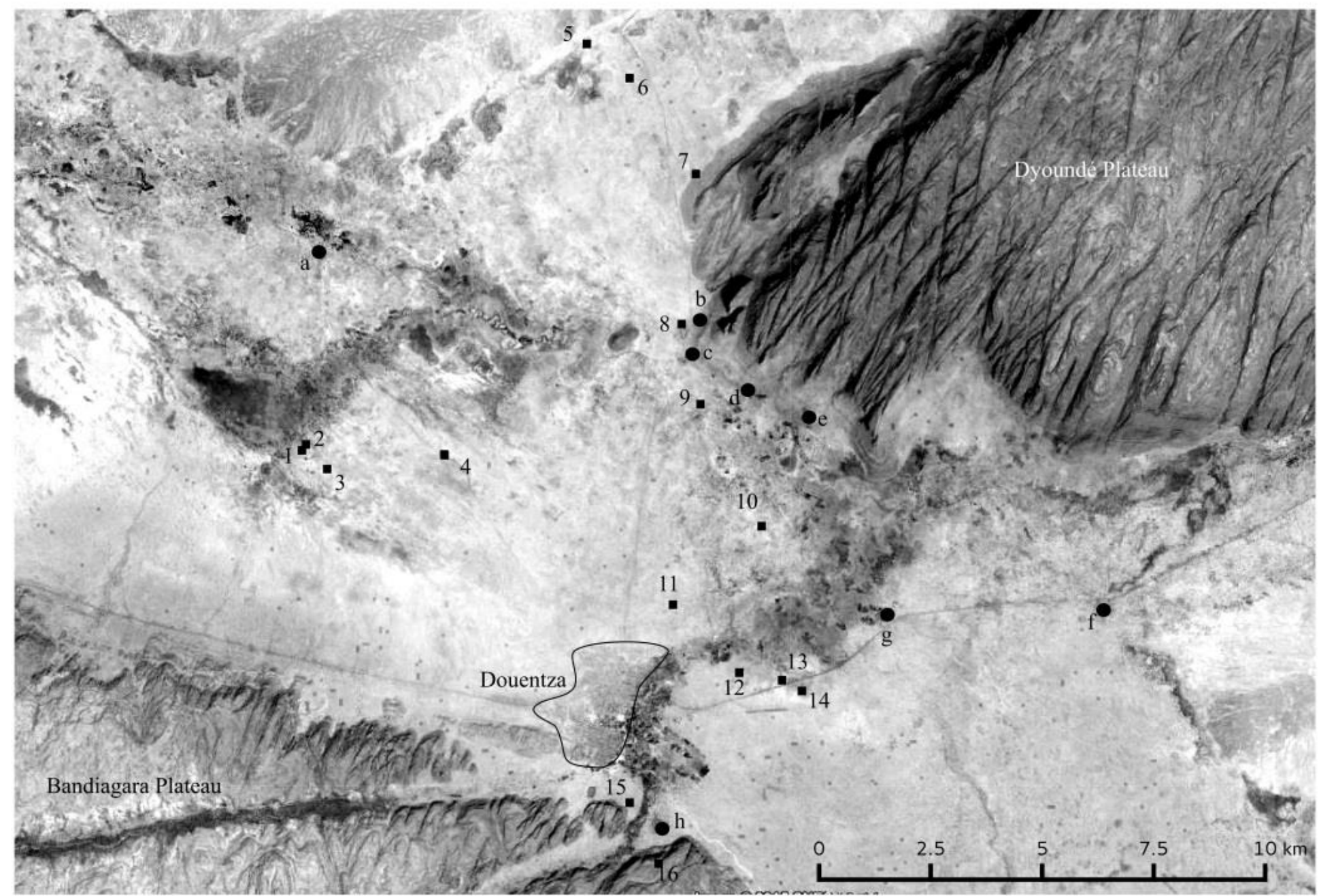

A

- Sites:

1 - Tangu 1

2 - Tangu 2

3 - Tangu 3

4 - Orowal Débéré

5 - MD23 (furnace)

6 - Tongo Maaré Amadou Garib

7 - Lumorde Hoore Nyiwa

8 - Boata (furnace)

9 - Tongo Maaré Sanga / Samtrou

10 - Tatore

11 - Tongo Maaré Diabal

12 - Ordjama

13 - N'gassa

14 - N'gassa Bodedjo

15 - DTZ07

16 - Fombori abandoned village and caves

- Villages:

a - Débéré

b - Boata

c - Tombori

d - Kara

e - Oualo

f - Sétaka

g - Dirimbé

h - Fombori

Figure 9: Satellite image overlay of surveyed area showing sites and areas of modern settlement 


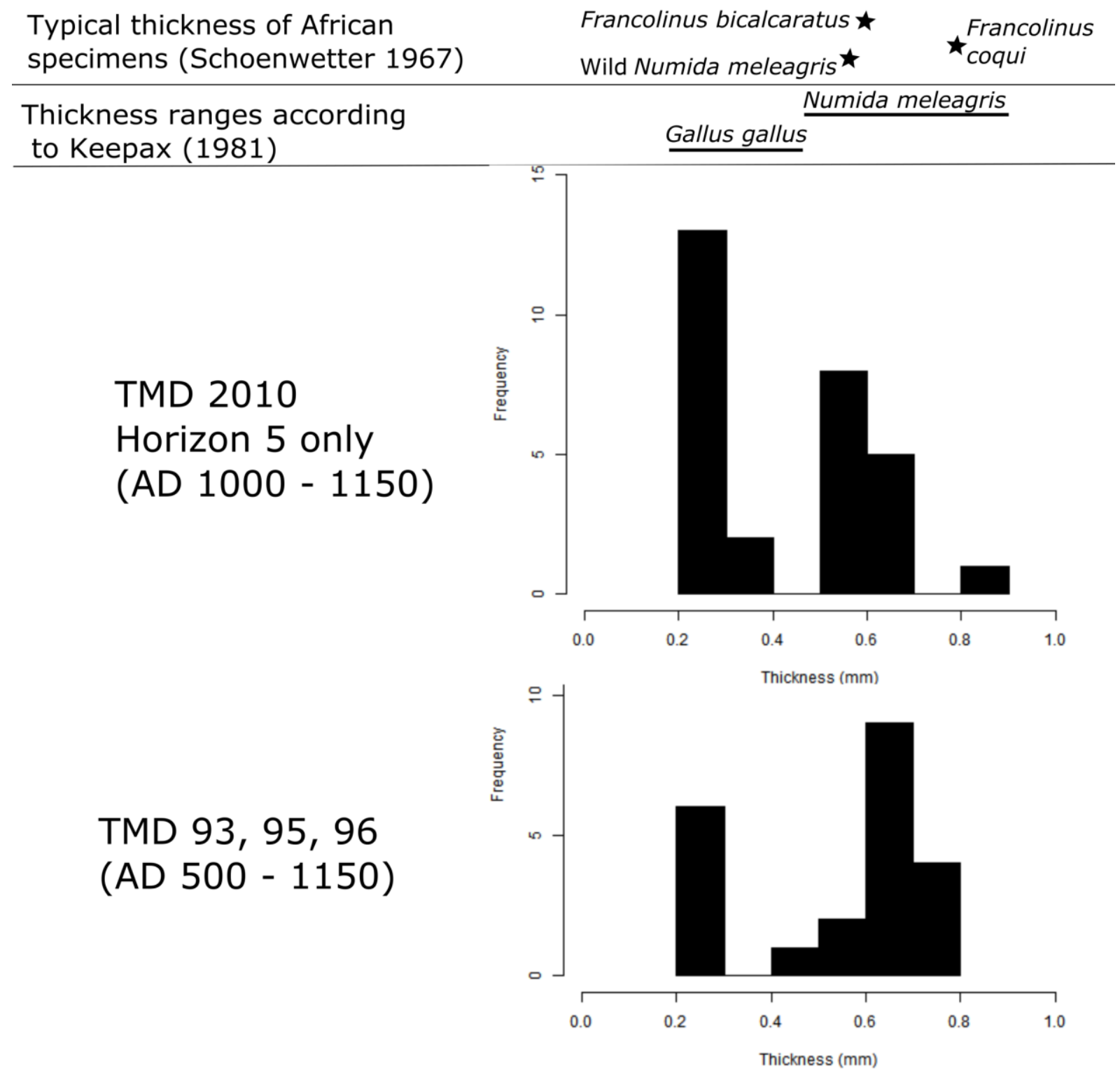

Figure 10: Thickness of egg shell fragments at TMD compared to published ranges by Keepax (1981) on European specimens and typical measurements by Schoenwetter (1967) on African specimens. 


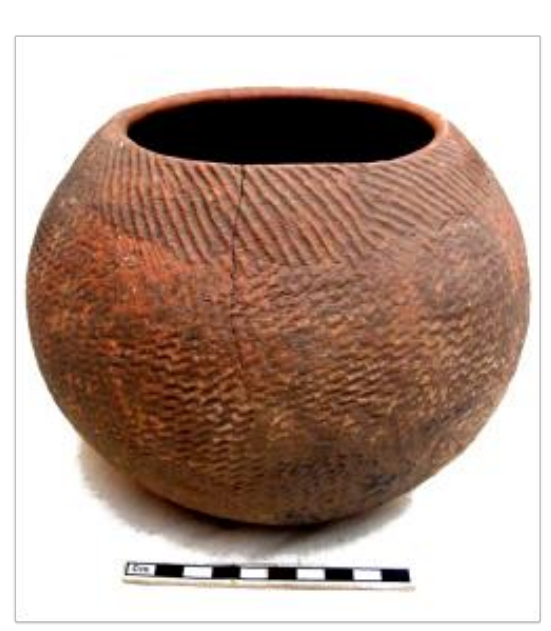

Tradition A

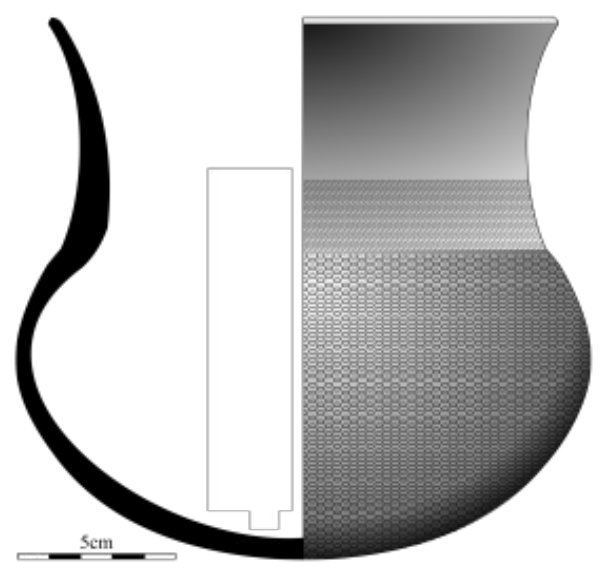

Tradition B
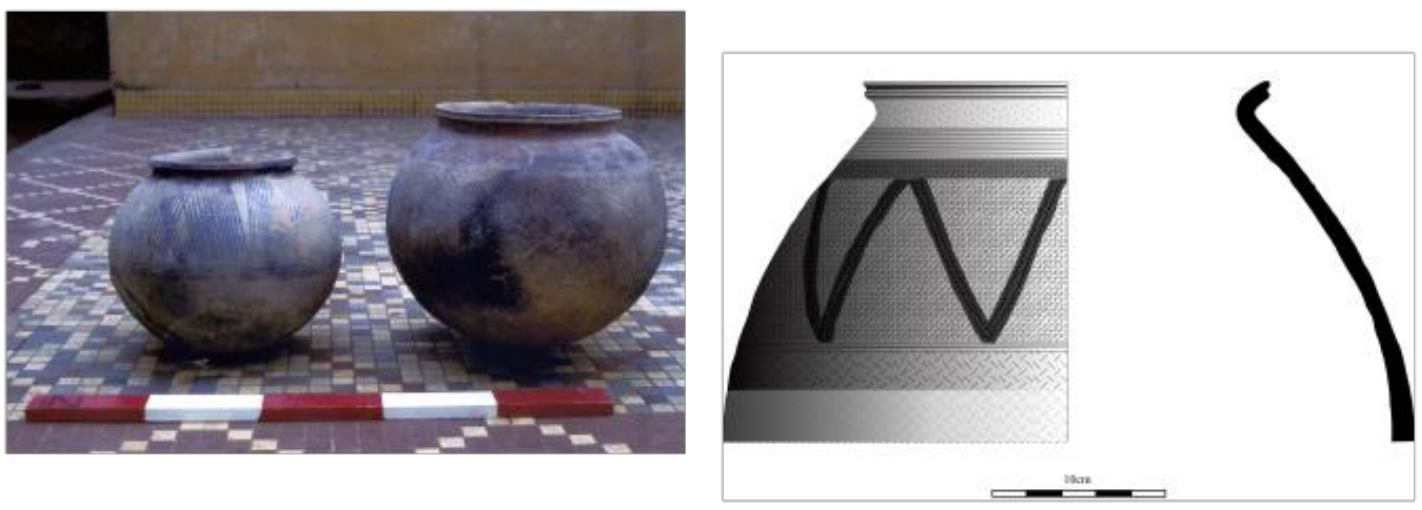

Figure 11: Photographed and illustrated examples of vessels from pottery traditions A and B
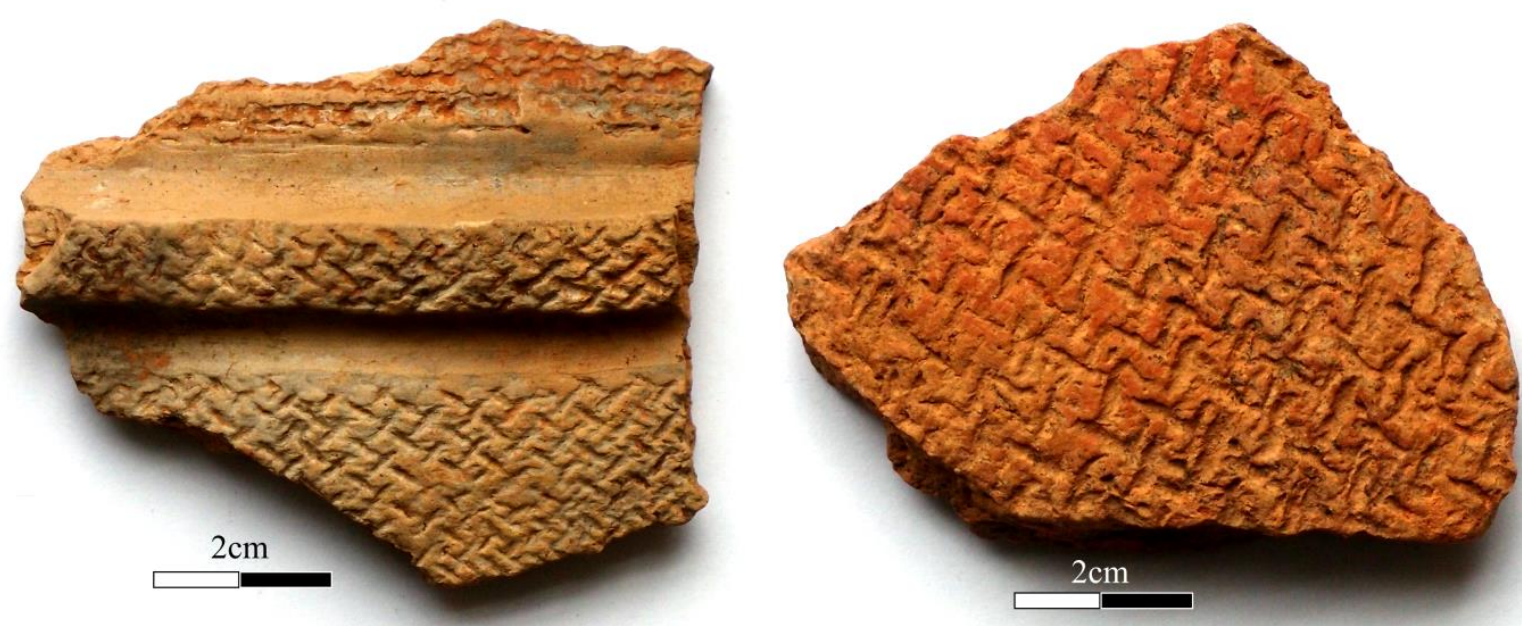

Figure 12: Two examples of sherds decorated with a complex braided cord roulette (CCR) 
Decor \% by Horizon

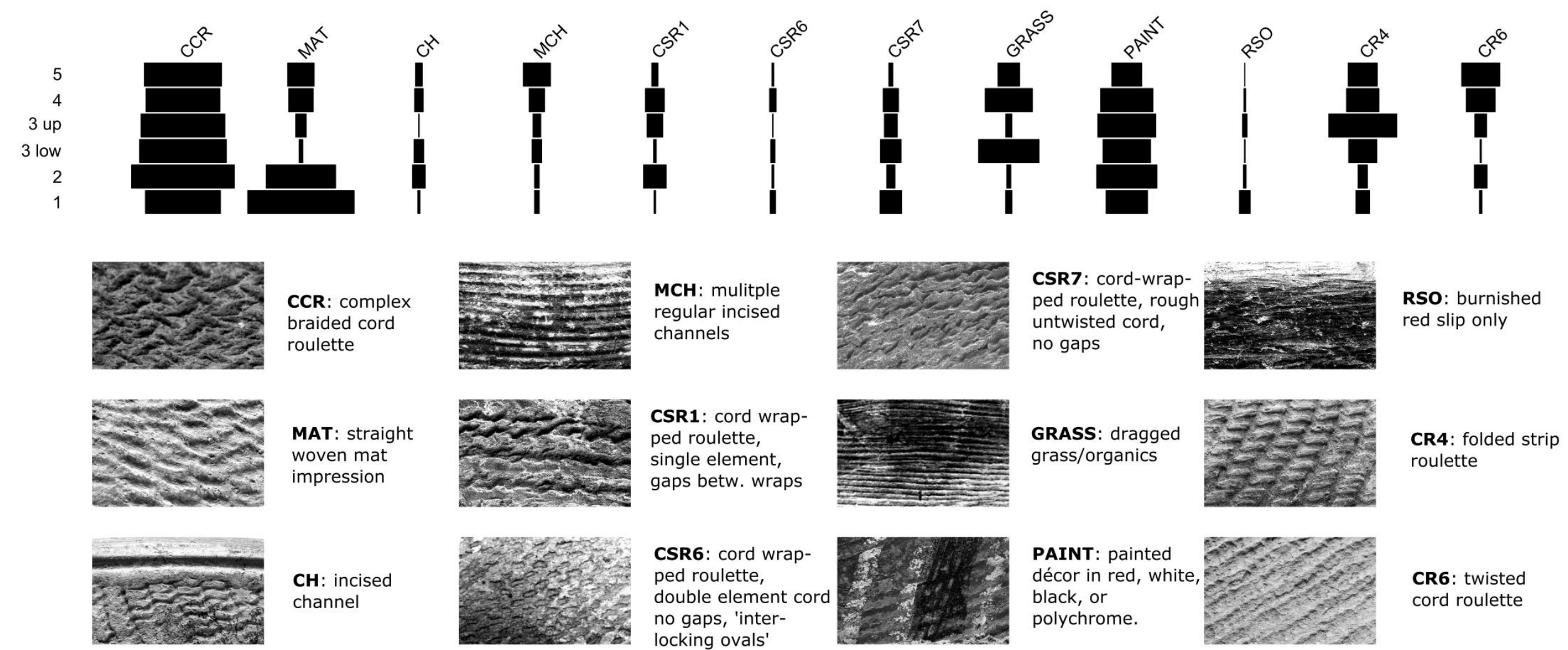

Figure 13: Percentages of pottery décor by horizon 


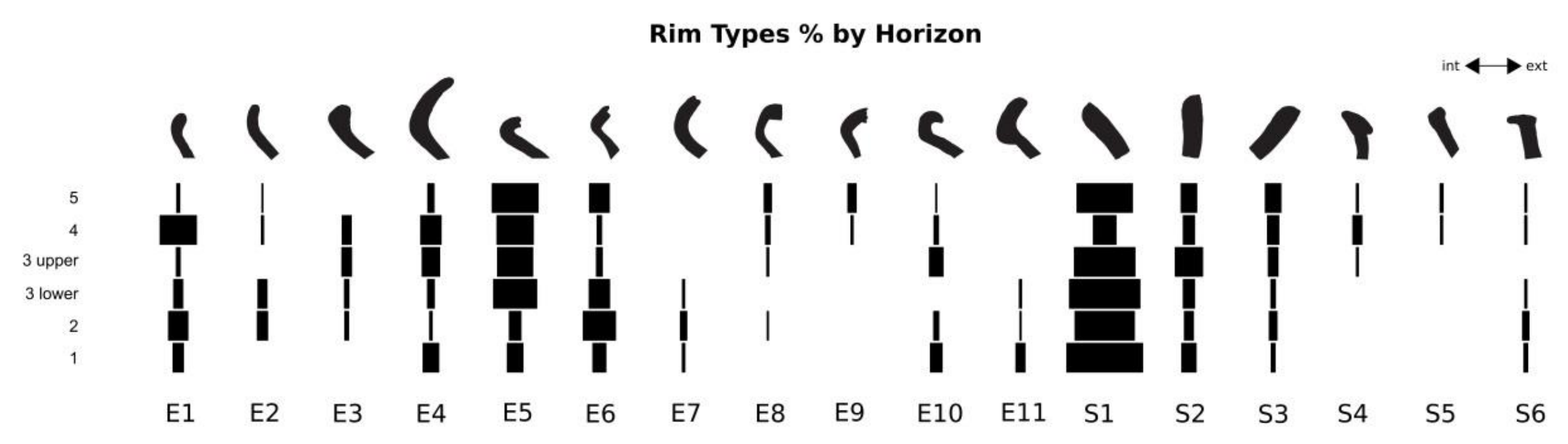

Figure 14: Percentages of main pottery rim types by horizon. 


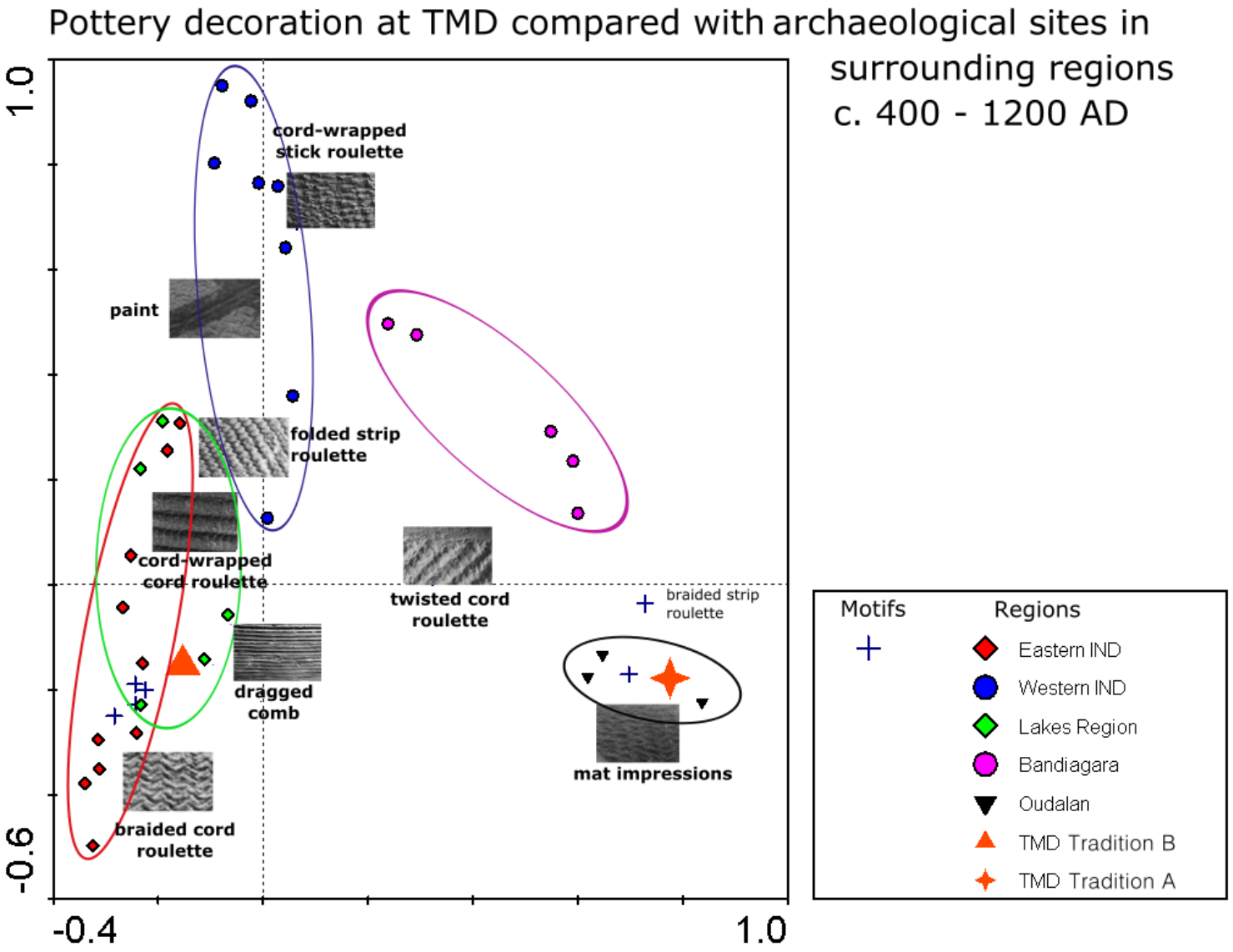

Figure 15: Biplot of a correspondence analysis showing the statistical similarity of TMD's traditions A and B to contemporary archaeological assemblages. Eastern IND: Jenné-Jeno, Hambarketolo, Kaniana, Toguéré Doupwil, Toguéré Galia, Tiébala; Western IND: Dia-Shoma, Dia-Mara; Lakes Region: Mouyssam II, Kawinza I; Bandiagara: Ounjougou rockshelter, Sangha cave sites; Oudalan: Saouga, Oursi Hu-Beero. Part of the analysis, but dismissed as outliers: Tombouze, Gao-Saney. Where possible, assemblages were separated into different phases, with a point for each phase. 


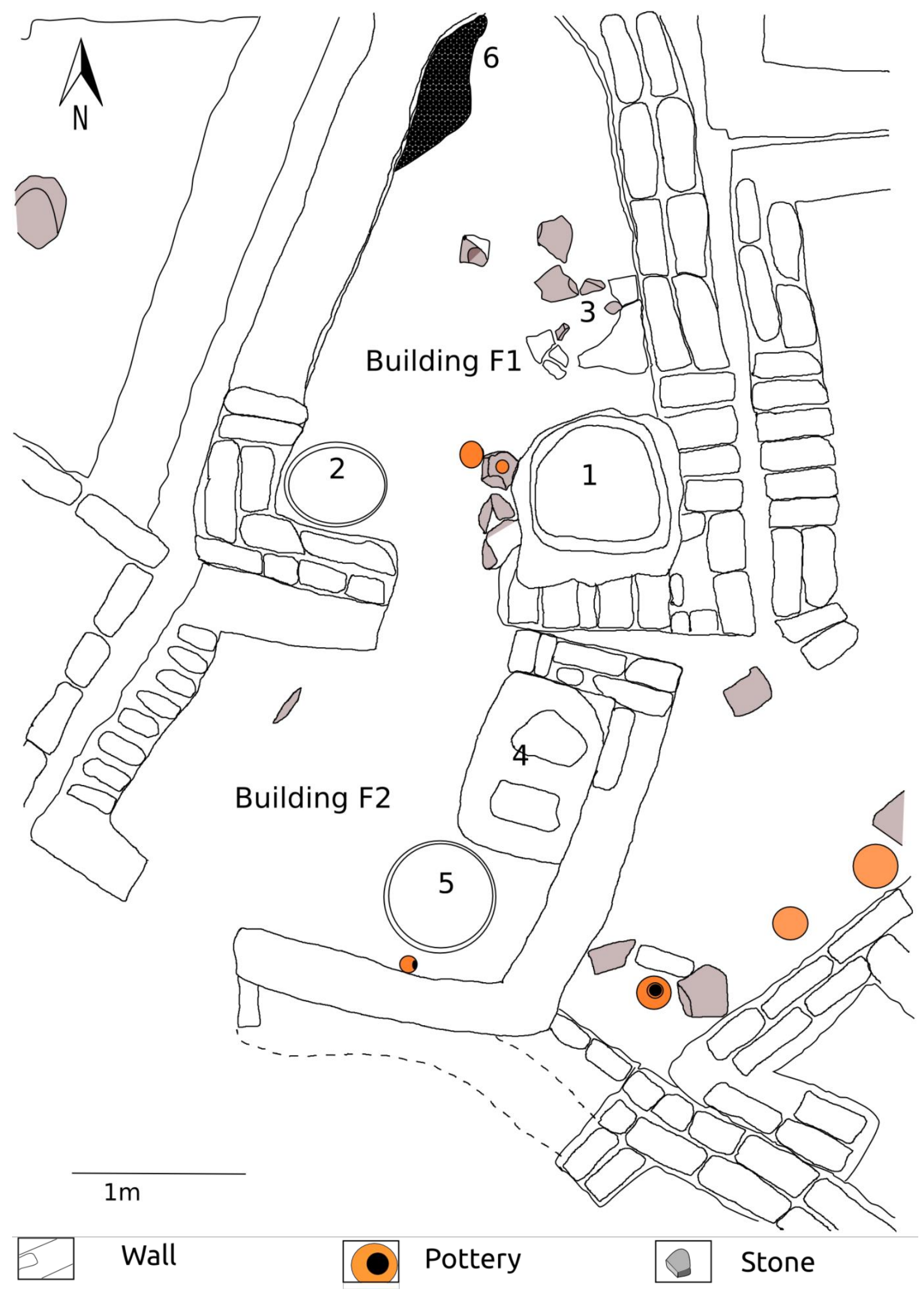

Figure 16: The area of the supposed blacksmith's workshop in Unit F 


\section{$\underline{\text { Tables: }}$}

\begin{tabular}{|c|c|c|c|c|c|c|}
\hline Context & $\underline{\text { Horizon }}$ & Uncal. bp & Cal. AD $(1 \sigma-68.2 \%)$ & Cal. AD $(2 \sigma-95.4 \%)$ & Lab No. & Material \\
\hline 95B-22 & 5 & $950 \pm 120$ & $990-1214$ & $778-1280$ & GX-21727 & charcoal \\
\hline 95A-19 & 5 & $1140 \pm 85$ & $777-981$ & $684-1025$ & GX-21868 & charcoal \\
\hline 95B-40 & 4 & $1105 \pm 80$ & $778-1019$ & $694-1147$ & GX-21728 & charcoal \\
\hline 93A-36 & $4 / 5$ & $1605 \pm 130$ & $264-592$ & $136-655$ & GX-19233 & charcoal \\
\hline 95B-66 & 3 lower & $1235 \pm 70$ & $690-874$ & $660-962$ & GX-21729 & textile \\
\hline $95 \mathrm{~A}-53$ & $2 / 3$ & $1200 \pm 110$ & $690-949$ & $642-1026$ & GX-21869 & charcoal \\
\hline 96B-93 & 1 & $1275 \pm 45$ & $676-770$ & $659-869$ & $\begin{array}{l}\text { GX- } \\
24103-L S\end{array}$ & charcoal \\
\hline $95 \mathrm{~A}-66$ & 1 & $1455 \pm 70$ & $543-655$ & $426-674$ & GX-21730 & charcoal \\
\hline 96D-13 & "5" & $1600 \pm 45$ & $408-535$ & $352-563$ & $\begin{array}{l}\text { GX- } \\
24104-L S\end{array}$ & charcoal \\
\hline
\end{tabular}

Table 1: Radiocarbon Dates from TMD Units A and B 


\begin{tabular}{|c|c|c|c|c|c|c|c|}
\hline NISP & & & & Horizo & & & \\
\hline Taxon & 1 & 2 & 3 lower & 3 upper & 4 & 5 & $5(2010)$ \\
\hline $\begin{array}{l}\text { Sylvicapra grimmia } \\
\text { Ourebia ourebi } \\
\text { Redunca redunca } \\
\text { Alcelaphinae } \\
\text { Alcelaphus buselaphus } \\
\text { Gazella rufifrons }\end{array}$ & 1 & 2 & 3 & 4 & 1 & $\begin{array}{l}1 \\
1 \\
1 \\
3\end{array}$ & $\begin{array}{l}1 \\
1 \\
3 \\
1 \\
1 \\
8\end{array}$ \\
\hline $\begin{array}{l}\text { Capra hircus } \\
\text { Ovis aries } \\
\text { Ovis/Capra }\end{array}$ & $\begin{array}{l}1 \\
3 \\
1\end{array}$ & $\begin{array}{c}1 \\
11\end{array}$ & 1 & $\begin{array}{l}6 \\
2 \\
8\end{array}$ & $\begin{array}{l}5 \\
13\end{array}$ & $\begin{array}{l}5 \\
18\end{array}$ & $\begin{array}{c}8 \\
3 \\
36\end{array}$ \\
\hline Bos sp. & 1 & 2 & 1 & 13 & 12 & 10 & 8 \\
\hline $\begin{array}{l}\text { small bovid } \\
\text { small medium bovid } \\
\text { large medium bovid } \\
\text { large bovid }\end{array}$ & $\begin{array}{c}3 \\
10\end{array}$ & $\begin{array}{c}2 \\
34 \\
5 \\
4 \\
\end{array}$ & $\begin{array}{c}3 \\
17 \\
2 \\
5\end{array}$ & $\begin{array}{c}3 \\
35 \\
1 \\
29 \\
\end{array}$ & $\begin{array}{c}10 \\
49 \\
2 \\
17\end{array}$ & $\begin{array}{c}3 \\
118 \\
5 \\
32\end{array}$ & $\begin{array}{l}14 \\
93 \\
20 \\
23 \\
\end{array}$ \\
\hline $\begin{array}{l}\text { Canis sp. } \\
\text { Felis sp. }\end{array}$ & 9 & 34 & 12 & 17 & 19 & $\begin{array}{c}52 \\
7\end{array}$ & $\begin{array}{c}81 \\
3\end{array}$ \\
\hline $\begin{array}{l}\text { Cricetomys gambianus } \\
\text { Thryonomys } \\
\text { swinderianus } \\
\text { Crocidura sp. } \\
\text { indeterminate rodent }\end{array}$ & & & $\begin{array}{l}2 \\
2\end{array}$ & 3 & $\begin{array}{l}7 \\
4 \\
1 \\
1\end{array}$ & $\begin{array}{l}1 \\
2\end{array}$ & 3 \\
\hline $\begin{array}{l}\text { Anhinga melanogaster } \\
\text { Anantinae } \\
\text { Gallus gallus } \\
\text { Gallus/Francolinus } \\
\text { Gallus/Numida } \\
\text { Numida } \\
\text { Streptopelia sp. } \\
\text { small medium bird } \\
\end{array}$ & 2 & 5 & & $\begin{array}{l}5 \\
1 \\
3 \\
3 \\
\\
3 \\
\end{array}$ & $\begin{array}{l}8 \\
2 \\
1\end{array}$ & $\begin{array}{c}2 \\
22 \\
1 \\
2\end{array}$ & $\begin{array}{c}1 \\
5 \\
7 \\
10 \\
1 \\
2 \\
1 \\
\end{array}$ \\
\hline $\begin{array}{l}\text { Polypterus sp. } \\
\text { Mormyridae } \\
\text { Gymnarchus niloticus } \\
\text { Bagridae } \\
\text { Auchenoglanis sp. } \\
\text { Clariidae } \\
\text { Synodontis sp. } \\
\text { Lates niloticus } \\
\text { Tilapiini }\end{array}$ & 3 & 15 & $\begin{array}{l}1 \\
6\end{array}$ & 3 & $\begin{array}{c}1 \\
10 \\
1 \\
3 \\
3\end{array}$ & $\begin{array}{c}1 \\
1 \\
1 \\
2 \\
2 \\
65 \\
3 \\
37 \\
31\end{array}$ & $\begin{array}{c}9 \\
2 \\
10 \\
14\end{array}$ \\
\hline
\end{tabular}

Table 2: Faunal Remains from TMD (NISP) 